\title{
Experimental Results of NWCF Run H-4 Calcine Dissolution Studies Performed in FY-98 and FY-99
}

T. G. Garn

R. S. Herbst

T. A. Batcheller

T. L. Sierra

August 2001

Idaho National Engineering and Environmental Laboratory Bechtel BWXT Idaho, LLC 


\title{
Experimental Results of NWCF Run H-4 Calcine Dissolution Studies Performed in FY-98 and $\mathbf{- 9 9}$
}

\author{
T. G. Garn \\ R. S. Herbst \\ T. A. Batcheller \\ T. L. Sierra
}

August 2001

Idaho National Engineering and Environmental Laboratory

Idaho Falls, Idaho 83415

Prepared for the

U.S. Department of Energy

Assistant Secretary for Environmental Management

Under DOE Idaho Operations Office

Contract DE-AC07-99ID13727 


\begin{abstract}
Dissolution experiments were performed on actual samples of NWCF Run H-4 radioactive calcine in fiscal years 1998 and 1999. Run H-4 is an aluminum/sodium blend calcine. Typical dissolution data indicates that between $90-95 \mathrm{wt} \%$ of $\mathrm{H}-4$ calcine can be dissolved using 1 gram of calcine per $10 \mathrm{mLs}$ of $5-8 \underline{\mathrm{M}}$ nitric acid at boiling temperature. Two liquid raffinate solutions composed of a WM-188/aluminum nitrate blend and a WM-185/aluminum nitrate blend were converted into calcine at the NWCF. Calcine made from each blend was collected and transferred to RAL for dissolution studies. The WM-188/aluminum nitrate blend calcine was dissolved with resultant solutions used as feed material for separation treatment experimentation. The WM-185/aluminum nitrate blend calcine dissolution testing was performed to determine compositional analyses of the dissolved solution and generate UDS for solid/liquid separation experiments. Analytical fusion techniques were then used to determine compositions of the solid calcine and UDS from dissolution. The results from each of these analyses were used to calculate elemental material balances around the dissolution process, validating the experimental data. This report contains all experimental data from dissolution experiments performed using both calcine blends.
\end{abstract}




\section{ACKNOWLEDGMENTS}

The authors wish to acknowledge the RAL analysts who put so much time and effort into the preparation and performance of the dissolution experiments. Those analysts include Alan Olaveson who performed all of the dissolution remote manipulator work, and Blaine Techmeyer, Richard Wells, and Neldon Jackson who provided analytical results from RAL.

The authors also wish to acknowledge the INTEC analytical department for their accurate and expeditious sample result reporting. Brian Storms, Dean Goodwin, Doug Thompson, and Stacy Hill who provided all of the radiochemistry data, Dennis Nielsen for spectrochemical data, and Greg Parks for anion data. Without the work ethic and dedication of these employees this work would never have been accomplished. 


\section{CONTENTS}

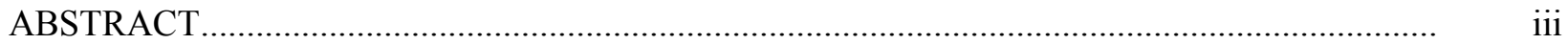

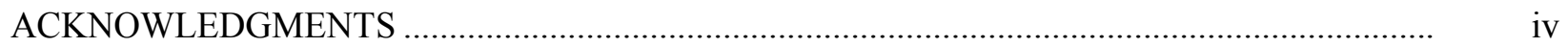

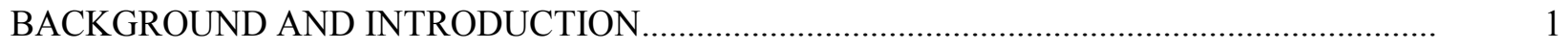

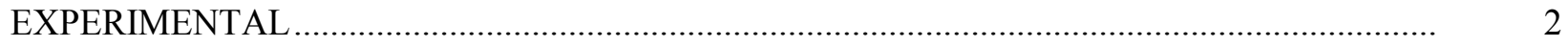

WM-188/Aluminum Nitrate Blend Calcine Dissolution Testing ...................................... 3

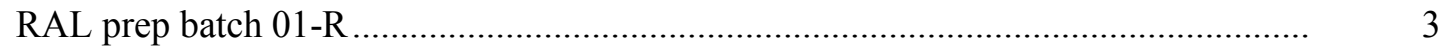

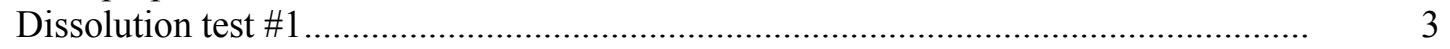

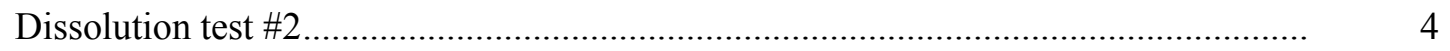

Dissolution test \#3 ....................................................................................... 5

WM-185/Aluminum Nitrate Blend Calcine Dissolution Testing ......................................... 5

Batch chloride .................................................................................................. 5

Calcine characterization and dissolution with elemental material balance.................. 5

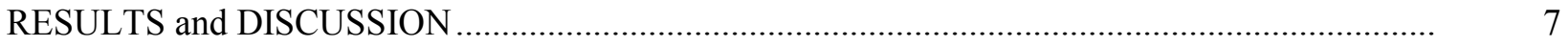

WM-188/Aluminum Nitrate Blend Dissolution Testing Results ..................................... 7

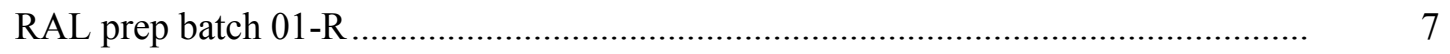

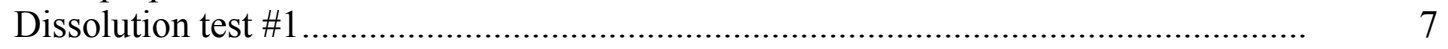

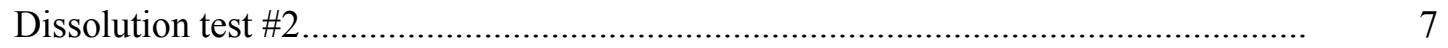

Dissolution test \#3 ..........................................................................................

WM-185/Aluminum Nitrate Blend Dissolution Testing Results ....................................... 9

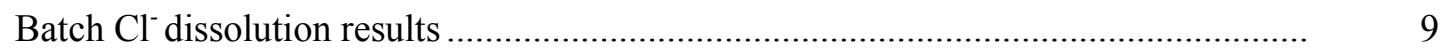

Calcine characterization results with elemental compositions..................................... 9

WM-185/aluminum nitrate blend calcine dissolutions ............................................ 12

Elemental material balance around dissolution of WM-185/aluminum nitrate blend .. 15

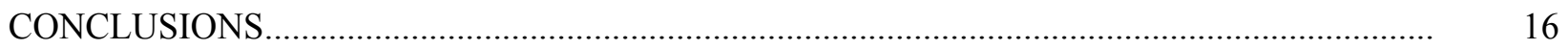

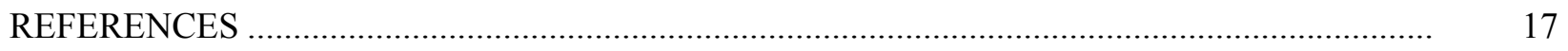

Appendix A—Dissolution Procedure …................................................................................ A-1

Appendix B-H-4 Calcine Material Balance Dissolution Raw Analytical Data............................ B-1 


\section{FIGURES}

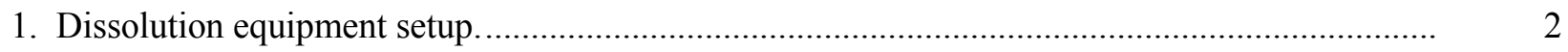

\section{TABLES}

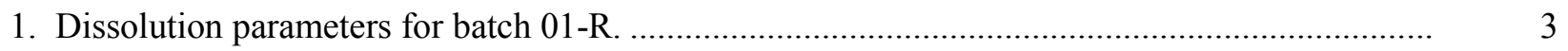

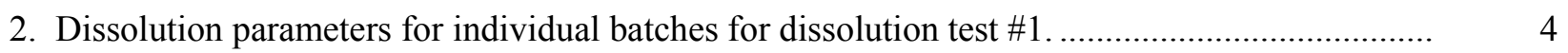

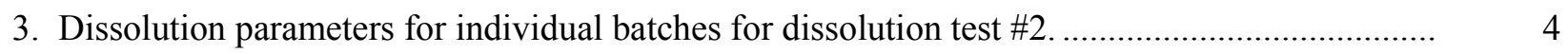

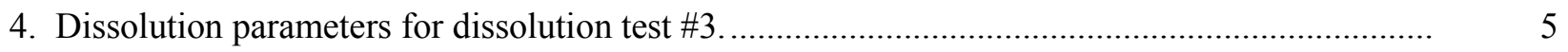

5. Dissolution parameters for batch chloride. …............................................................... 5

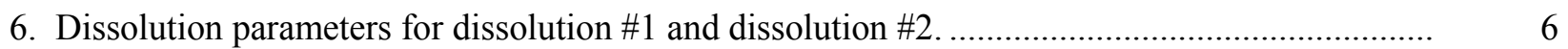

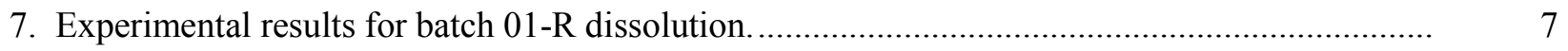

8. Experimental results from WM-188 blend dissolution tests \#1, \#2, and \#3.............................. 8

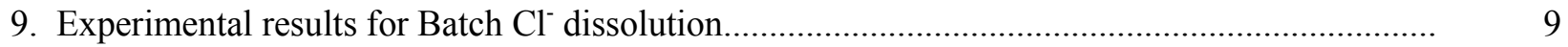

10. Elemental composition of WM-185/aluminum nitrate calcine ............................................... 10

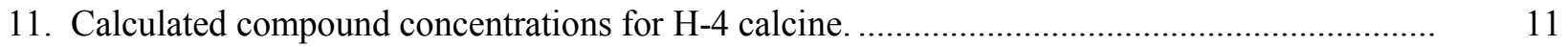

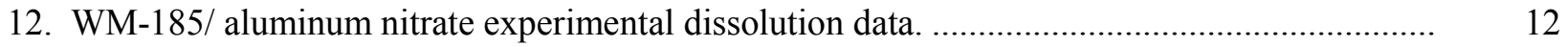

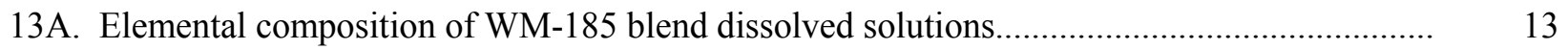

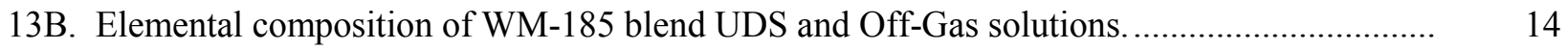

14. Elemental material balance for WM-185 blend calcine dissolution. ........................................ 15 


\section{Experimental Results of NWCF Run H-4 Calcine Dissolution Studies Performed in FY-98 and -99 BACKGROUND AND INTRODUCTION}

In 1995, a settlement agreement was reached between the State of Idaho and the U.S. Department of Energy. Sections of the agreement mandated treatment of high level radioactive calcine waste currently stored at the Idaho Nuclear Technology and Engineering Center (INTEC) at the Idaho National Engineering and Environmental Laboratory (INEEL). Treatment includes processing the calcine for transport to a national repository by the year 2035 .

Radioactive calcine is the product of calcination of radioactive raffinates originating from nuclear fuel reprocessing activities previously conducted at INTEC. The calcination process converted liquid raffinates into granular solid material reducing storage volume and leakage potential. Due to the numerous types of fuels reprocessed at INTEC, there is a variety of calcine compositions in storage. The calcine is stored in stainless steel bins encased in cylindrical concrete vaults known as Calcined Solids Storage Facilities (CSSFs). The CSSF structures are commonly referred to as binsets. There are seven binsets constructed at INTEC with six presently storing calcine. The volume of calcine stored is currently estimated at roughly $4200 \mathrm{~m}^{3}$.

Calcine dissolution is the key front-end unit operation of several separations' treatment options under consideration as documented in the Draft Environmental Impact Statement [8]. To support the investigation of various treatment options, dissolved calcine solutions were used as feedstock for solid/liquid separations, ion exchange, and solvent extraction experiments performed in the Remote Analytical Laboratory (RAL) in 1998-99.

NWCF Run H-4 Calcine included two feed blends, WM-188/aluminum nitrate and WM-185/aluminum nitrate. Samples pulled from the WM-188/aluminum nitrate blend calcine were dissolved to determine percent dissolution and provide feedstock solutions for AMP-PAN and FS-2 ion exchange experiments, solid/liquid separations using the cells unit cross-flow filter (CUF), and the universal extraction (UNEX) solvent extraction experiment. Samples pulled from the WM-185/aluminum nitrate blend calcine were used for dissolution testing, characterization determinations, and to calculate elemental material balance for calcine dissolution. This report documents the compositional data and calculated results for numerous radioactive $\mathrm{H}-4$ calcine dissolution experiments performed in FY-98 and -99. 


\section{EXPERIMENTAL}

All Run H-4 radioactive calcine dissolution experiments were conducted in the RAL hot cell. The cell provides radiation shielding necessary to handle radioactive material remotely with manipulators. Using manipulators, RAL analysts assembled the dissolution setup using standard equipment. A typical dissolution experimental setup is shown in Figure 1. The standard equipment setup consisted of a 1-liter glass dissolver, stirrer/hotplate, and reflux condenser. The dissolver was placed on a stirrer/hotplate with a reflux condenser inserted in the top of the dissolver allowing cooling water to reflux the acid vapors exiting the system.

Dissolution parameters were varied slightly as needed to provide appropriate quantities and compositions of the dissolved calcine product to separations'experimenters. For example the CUF required ample solids to evaluate solid/liquid separation effectiveness, while the ion exchange and solvent extraction experiments required specifically requested dissolved solution acid concentrations for desired separation effectiveness.

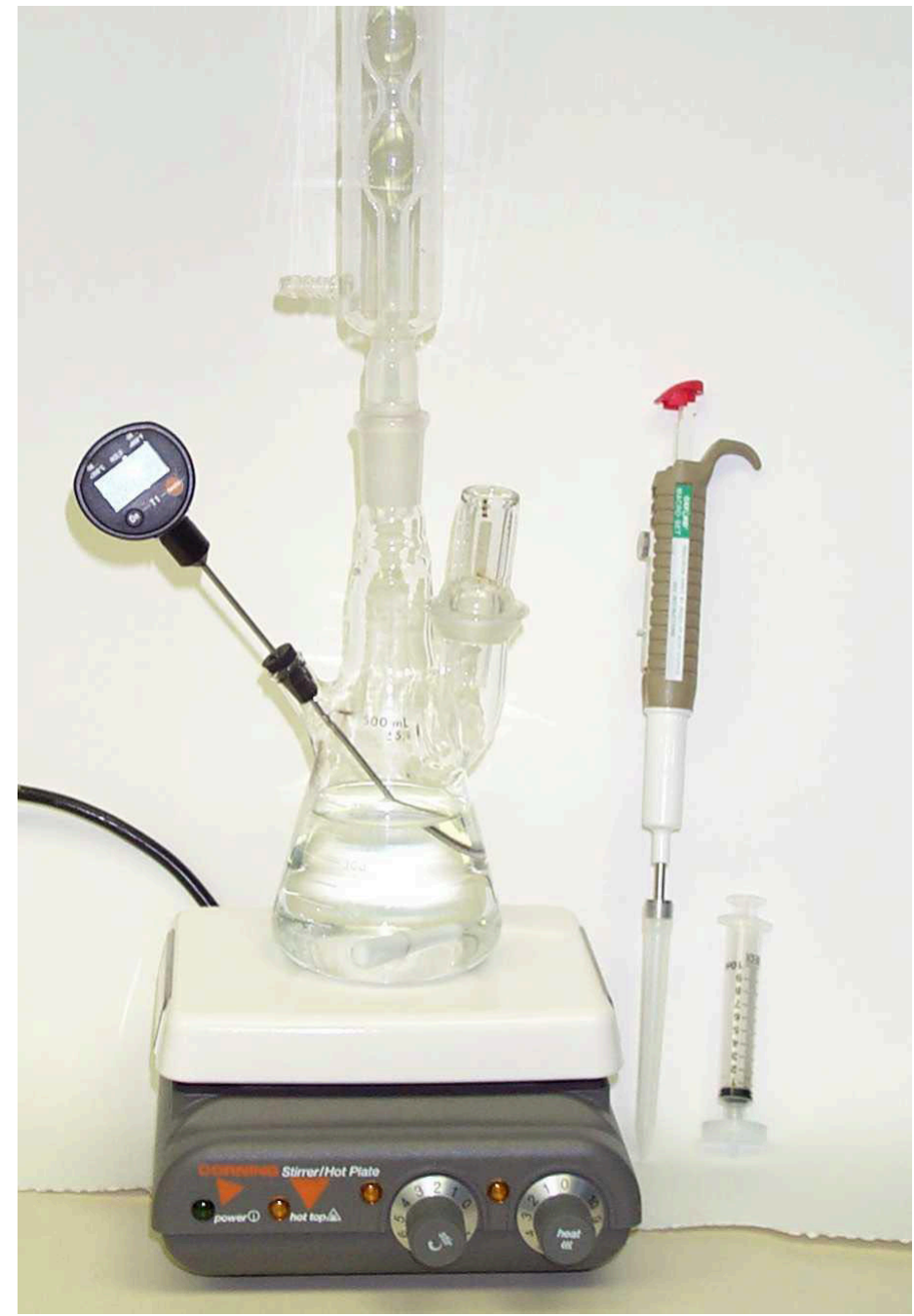

Figure 1. Dissolution equipment setup. 
The generic dissolution procedure consisted of adding a measured volume of nitric acid to the dissolver, heating to desired temperature, adding the measured mass of calcine, and observe dissolution for a set amount of time. (The specific dissolution procedure is found in Appendix A.) When the time had been reached, the solution was allowed to cool and any undissolved solids (UDS) were given time to settle prior to filtering solution through a tared 0.45 micron Cole Parmer filter unit. The filtered solution was transferred into an appropriately labeled bottle for use in separation experiments. The filter containing the UDS was then allowed to dry then weighed. The UDS weight was then calculated and percent dissolution was determined by:

$$
w t \% \text { dissolution }=\left[1-\frac{U D S w t}{\text { Initial Calcine } w t}\right] * 100 \%
$$

\section{WM-188/Aluminum Nitrate Blend Calcine Dissolution Testing}

There were four sets of dissolution testing. Details for each set of testing follows.

\section{RAL prep batch 01-R}

An initial dissolution of WM-188/aluminum nitrate blend calcine was performed to determine fission product concentration, weight percent dissolution, and acid consumption (moles of acid used to dissolve 1 gram of calcine). The filtered solution was submitted for cesium, strontium, and gamma scan analyses. Table 1 provides the experimental parameters associated with batch $01-\mathrm{R}$.

Table 1. Dissolution parameters for batch 01-R.

\begin{tabular}{c|ccccc} 
Batch & $\begin{array}{c}\text { Calcine } \\
\text { added } \\
\text { (grams) }\end{array}$ & $\begin{array}{c}\text { HNO3 acid } \\
\text { (molarity) }\end{array}$ & $\begin{array}{c}\text { Volume } \\
\text { added (liters) }\end{array}$ & $\begin{array}{c}\text { Dissolution } \\
\text { time } \\
\text { (minutes) }\end{array}$ & Temperature \\
\hline $01-\mathrm{R}$ & 28.956 & 8.0 & 0.290 & 30 & boiling
\end{tabular}

\section{Dissolution test \#1}

A dissolution test \#1 was performed. This test was performed in a series of four batch experiments. The parameters for the four batch experiments were $1 \mathrm{~g}$ calcine $/ 10 \mathrm{~mL}$ acid ratio, 4.5 or $9.0 \mathrm{M}$ nitric acid, 1.5 hour dissolution time, and boiling temperature of solution. (Batch 3 was dissolved in $9.0 \underline{\mathrm{M}}$ nitric acid). The dissolved solutions were combined and used as feedstock for AMP-PAN cesium ion exchange testing. The target final acid concentration of the dissolved solution was $2.0 \underline{\mathrm{M} \mathrm{H}^{+}}$(this is the reason there were two different nitric acid concentrations used). A final volume of 2.1 liters was collected for ion exchange testing. Table 2 provides the individual batch experimental parameters for dissolution test \#1. 
Table 2. Dissolution parameters for individual batches for dissolution test \#1.

\begin{tabular}{c|ccccc} 
Batch & $\begin{array}{c}\text { Calcine } \\
\text { added } \\
\text { (grams) }\end{array}$ & $\begin{array}{c}\text { HNO } \text { acid } \\
\text { (molarity) }\end{array}$ & $\begin{array}{c}\text { Volume } \\
\text { added (liters) }\end{array}$ & $\begin{array}{c}\text { Dissolution } \\
\text { time } \\
\text { (minutes) }\end{array}$ & Temperature \\
\hline$\# 1$ & 54.054 & 4.5 & 0.541 & 75 & boiling \\
$\# 2$ & 51.593 & 4.5 & 0.516 & 95 & boiling \\
$\# 3$ & 59.883 & 9.0 & 0.600 & 90 & boiling \\
$\# 4$ & 25.303 & 4.5 & 0.255 & 90 & boiling
\end{tabular}

\section{Dissolution test \#2}

Dissolution test \#2 also incorporated a series of four batch experiments. The final filtered solutions were combined to provide a feedstock solution for ion exchange testing. Approximately 1.5 liters was collected for use with the ion exchange testing. Final acid concentration was measured after the solutions were combined. Weight percent dissolution was not calculated because of solids losses occurring during routine remote activities in the hot cell. Table 3 provides the individual batch parameters for dissolution test \#2.

Table 3. Dissolution parameters for individual batches for dissolution test \#2.

\begin{tabular}{c|ccccc} 
Batch & $\begin{array}{c}\text { Calcine } \\
\text { added } \\
\text { (grams) }\end{array}$ & $\begin{array}{c}\text { HNO } \text { acid } \\
\text { (molarity) }\end{array}$ & $\begin{array}{c}\text { Volume } \\
\text { added (liters) }\end{array}$ & $\begin{array}{c}\text { Dissolution } \\
\text { time } \\
\text { (minutes) }\end{array}$ & Temperature \\
\hline$\# 1$ & 26.085 & 5.1 & 0.261 & 90 & boiling \\
$\# 2$ & 41.936 & 5.1 & 0.420 & 90 & boiling \\
$\# 3$ & 48.912 & 5.13 & 0.490 & 90 & boiling \\
$\# 4$ & 49.09 & 5.13 & 0.491 & 90 & boiling
\end{tabular}




\section{Dissolution test \#3}

Dissolution test \#3 was performed to provide feedstock solution for UNEX solvent extraction batch contacts. Solvent extraction batch contacts need small volumes of solution; consequently, only one batch dissolution was performed. Approximately 0.4 liters of filtered solution was collected from the single batch test. Final acid concentration was measured and the weight percent dissolution was calculated for test \#3. Table 4 provides test parameters for dissolution test \#3.

Table 4. Dissolution parameters for dissolution test \#3.

\begin{tabular}{c|ccccc} 
Batch & $\begin{array}{c}\text { Calcine } \\
\text { added } \\
\text { (grams) }\end{array}$ & $\begin{array}{c}\text { HNO } \text { acid } \\
\text { (molarity) }\end{array}$ & $\begin{array}{c}\text { Volume } \\
\text { added (liters) }\end{array}$ & $\begin{array}{c}\text { Dissolution } \\
\text { time } \\
\text { (minutes) }\end{array}$ & Temperature \\
\hline$\# 1$ & 39.151 & 5.1 & 0.392 & 90 & boiling
\end{tabular}

\section{WM-185/Aluminum Nitrate Blend Calcine Dissolution Testing}

Two sets of dissolution testing were performed using the WM-185/aluminum nitrate blend calcine. Details for these tests follow.

\section{Batch chloride}

The batch chloride dissolution experiment was performed to determine chloride concentration, final dissolved solution acid concentration, and weight percent dissolved for the WM-185/aluminum nitrate blend calcine. The experiment utilized the identical equipment as was used with the WM-188/aluminum nitrate blend calcine experiments. Table 5 provides test parameters used for batch chloride test.

Table 5. Dissolution parameters for batch chloride.

\begin{tabular}{c|ccccc} 
Batch & $\begin{array}{c}\text { Calcine } \\
\text { added } \\
\text { (grams) }\end{array}$ & $\begin{array}{c}\text { HNO3 acid } \\
\text { (molarity) }\end{array}$ & $\begin{array}{c}\text { Volume } \\
\text { added (liters) }\end{array}$ & $\begin{array}{c}\text { Dissolution } \\
\text { time } \\
\text { (minutes) }\end{array}$ & Temperature \\
\hline Batch $\mathrm{Cl}^{-}$ & 20.181 & 5.1 & 0.201 & 60 & Boiling
\end{tabular}

\section{Calcine characterization and dissolution with elemental material balance}

Prior to initiating calcine dissolution, the calcine was fully characterized using fusion methods for solids elemental characterization. The analytical department uses three fusion methods for determining solid elemental compositions. These methods use lithium tetraborate, sodium hydroxide, or sodium carbonate dependent on which analyte is desired. Lithium tetraborate fusion is used for most metals and radioactive elements. Sodium hydroxide fusion is used for lithium, boron, and anions. Sodium carbonate fusion is used for the remaining anions that form difficult to dissolve complexes such as phosphate. Fusion methodology begins by mixing a measured mass of sample with one of the three compounds at a-1:10 ratio, heating at high temperature in a furnace to form a melt, redissolving the melt in a chosen solvent, and submitting the solvent matrix for elemental analysis. Two independent characterizations were performed to provide elemental analyses of the calcine prior to performing dissolutions. The elemental analyses provided initial starting elemental compositions for use in material balance determinations. 
Two dissolutions were performed to determine the material balance around H-4 calcine dissolution. The experimental setup was modified to allow for off-gas to be routed through two scrubber vessels set in series flow. The first scrubber was filled with $100 \mathrm{~mL}$ of $1 \underline{\mathrm{M}}$ sodium hydroxide and the second scrubber filled with $100 \mathrm{~mL}$ of $1 \underline{\mathrm{M}}$ nitric acid. The purpose of the scrubber additions was to determine if any volatile elements were escaping through the off-gas. The other difference from previous dissolutions was the addition of Tc-99 and I-129 to dissolution \#1. Spiking with Tc-99 and I-129 increases the concentration of Tc-99 and I-129 to levels above analytical detection limits in an attempt to determine the fate of the two volatile species during dissolution.

At the completion of the dissolutions, the UDS were weighed to determine percent dissolved. The UDS were then recovered and characterized in the same manner as the initial calcine mass using analytical fusion methods. The elemental material balance surrounding dissolution was then calculated by adding elemental results from the dissolved solution with the UDS and off-gas results and dividing the sum by the initial elemental mass results in the calcine. Table 6 provides dissolution parameters used for dissolution \#1 and dissolution \#2.

Table 6. Dissolution parameters for dissolution \#1 and dissolution \#2.

\begin{tabular}{c|ccccc} 
Batch & $\begin{array}{c}\text { Calcine } \\
\text { added } \\
\text { (grams) }\end{array}$ & $\begin{array}{c}\text { HNO3 acid } \\
\text { (molarity) }\end{array}$ & $\begin{array}{c}\text { Volume } \\
\text { added (liters) }\end{array}$ & $\begin{array}{c}\text { Dissolution } \\
\text { time } \\
\text { (minutes) }\end{array}$ & Temperature \\
\hline Dissolution \#1 & 10.001 & 8.0 & 0.100 & 120 & Boiling \\
Dissolution \#2 & 10.005 & 8.0 & 0.001 & 120 & Boiling
\end{tabular}




\section{RESULTS AND DISCUSSION}

\section{WM-188/Aluminum Nitrate Blend Dissolution Testing Results}

\section{RAL prep batch 01-R}

The dissolution of this batch was the initial dissolution performed using the WM-188/aluminum nitrate blend calcine. Requested analytes from the dissolved solution included cesium, strontium, and gamma emitting isotopes. Weight percent dissolved, final acid concentration, and acid consumption was determined for batch 01-R dissolved solution. Table 7 presents the experimental results for batch 01-R.

Table 7. Experimental results for batch 01-R dissolution.

\begin{tabular}{c||cc|cc|cccc}
\hline $\begin{array}{c}\text { Dissolution } \\
\text { Results }\end{array}$ & $\begin{array}{c}\text { Wt \% } \\
\text { Dissolved }\end{array}$ & $93.5 \%$ & $\begin{array}{c}\text { Final acid } \\
\text { Conc. }\end{array}$ & $5.015 \underline{M}$ & $\begin{array}{c}\text { Acid } \\
\text { consumed }\end{array}$ & $\begin{array}{c}0.03 \\
\text { mol/gram }\end{array}$ & & \\
\hline \hline \multirow{2}{*}{ Analytes } & $\begin{array}{c}\text { Cesium } \\
(\mathrm{ug} / \mathrm{mL})\end{array}$ & $\begin{array}{c}\text { Strontium } \\
(\mathrm{ug} / \mathrm{mL})\end{array}$ & $\begin{array}{c}\mathrm{Eu}-154 \\
(\mathrm{dps} / \mathrm{mL})\end{array}$ & $\begin{array}{c}\mathrm{Eu}-155 \\
(\mathrm{dps} / \mathrm{mL})\end{array}$ & $\begin{array}{c}\mathrm{Cs}-134 \\
(\mathrm{dps} / \mathrm{mL})\end{array}$ & $\begin{array}{c}\mathrm{Cs}-137 \\
(\mathrm{dps} / \mathrm{mL})\end{array}$ & $\begin{array}{c}\mathrm{Zr}-95 \\
(\mathrm{dps} / \mathrm{mL})\end{array}$ & $\begin{array}{c}\mathrm{Co}-60 \\
(\mathrm{dps} / \mathrm{mL})\end{array}$ \\
\hline $\begin{array}{c}\text { Analytical } \\
\text { data }\end{array}$ & 4.19 & 9.1025 & $1.74 \mathrm{E}+04$ & $5.08 \mathrm{E}+03$ & $1.48 \mathrm{E}+04$ & $3.89 \mathrm{E}+06$ & $1.35 \mathrm{E}+03$ & $4.11 \mathrm{E}+03$ \\
\hline
\end{tabular}

\section{Dissolution test \#1}

Final dissolved solutions from four batches were combined to provide a feedstock solution for AMP-PAN ion exchange testing. The final solution was analyzed for those elements impacting ion exchange performance. A weight percent dissolved was calculated using UDS weights from the four batches and the total weight of calcine added to all four batches. The final dissolved acid concentration was measured and the acid consumed was calculated. Table 8 presents the analytical data and dissolution results from the final dissolved solution combined from the four batch dissolution solutions.

\section{Dissolution test \#2}

Final dissolved solutions from four batches were combined to provide a feedstock solution for other ion exchange testing. The final solution was analyzed for chosen elements impacting ion exchange efforts. The final dissolved acid concentration was measured and the acid consumed was calculated. Weight percent dissolved was not calculated due to a loss of solids during batch \#1 and batch \#4 testing in the hot cell. Table 8 presents the analytical data and dissolution results from the final dissolved solution combined from the four batch dissolution solutions. 


\section{Dissolution test \#3}

Final dissolved solution provided a feedstock solution for UNEX solvent extraction batch contacts. The final solution was analyzed for chosen elements impacting solvent extraction efforts. A weight percent dissolved was calculated using UDS weight and the initial calcine weight added to the dissolver. The final dissolved acid concentration was measured and the acid consumed was calculated. Table 8 presents the analytical data and dissolution results from the final dissolved solution.

Table 8. Experimental results from WM-188 blend dissolution tests \#1, \#2, and \#3.

\begin{tabular}{|c|c|c|c|}
\hline \multicolumn{4}{|c|}{ METAL and ANION RESULTS (ug/mL) } \\
\hline & Test \#1 & Test $\# 2$ & Test \#3 \\
\hline Aluminum & $2.92 \mathrm{E}+04$ & $2.93 \mathrm{E}+04$ & $2.79 \mathrm{E}+04$ \\
\hline Barium & NR & NR & $<3.10 \mathrm{E}+00$ \\
\hline Boron & NR & NR & $4.93 \mathrm{E}+02$ \\
\hline Cadmium & NR & $4.20 \mathrm{E}+01$ & NR \\
\hline Calcium & $6.93 \mathrm{E}+03$ & NR & $3.00 \mathrm{E}+03$ \\
\hline Cesium & $9.13 \mathrm{E}+00$ & $<5.57 \mathrm{E}+00$ & NR \\
\hline Chloride & $<4.86 \mathrm{E}+01$ & $2.83 \mathrm{E}+02$ & $<2.44 \mathrm{E}+01$ \\
\hline Chromium & $2.11 \mathrm{E}+02$ & NR & $\mathrm{NR}$ \\
\hline Fluoride & $9.48 \mathrm{E}-01$ & $2.64 \mathrm{E}-02$ & $4.37 \mathrm{E}+02$ \\
\hline Iron & $9.86 \mathrm{E}+02$ & $2.94 \mathrm{E}+02$ & $2.51 \mathrm{E}+02$ \\
\hline Lead & $6.75 \mathrm{E}+01$ & $8.36 \mathrm{E}+01$ & $3.55 \mathrm{E}+01$ \\
\hline Mercury & $5.72 \mathrm{E}+00$ & $<1.76 \mathrm{E}+00$ & $4.34 \mathrm{E}+00$ \\
\hline Nickel & $1.10 \mathrm{E}+02$ & $1.82 \mathrm{E}+01$ & NR \\
\hline Potassium & $1.28 \mathrm{E}+03$ & $1.32 \mathrm{E}+03$ & $1.50 \mathrm{E}+03$ \\
\hline Sodium & $4.02 \mathrm{E}+03$ & $6.62 \mathrm{E}+03$ & $5.51 \mathrm{E}+03$ \\
\hline Strontium & $9.00 \mathrm{E}+00$ & $<11.30 \mathrm{E}+00$ & NR \\
\hline Zinc & NR & NR & $2.20 \mathrm{E}+01$ \\
\hline Zirconium & $3.26 \mathrm{E}+02$ & $1.40 \mathrm{E}+02$ & NR \\
\hline \multicolumn{4}{|c|}{ RADIOACTIVE RESULTS (dps/mL) } \\
\hline Am-241 & $\mathrm{NR}$ & $\mathrm{NR}$ & $6.01 \mathrm{E}+02$ \\
\hline Co-60 & NR & $4.16 \mathrm{E}+02$ & $1.73 \mathrm{E}+03$ \\
\hline Cs-134 & NR & NR & $3.73 \mathrm{E}+03$ \\
\hline Cs-137 & $8.37 \mathrm{E}+06$ & $1.12 \mathrm{E}+06$ & $5.35 \mathrm{E}+06$ \\
\hline Eu-154 & NR & $3.11 \mathrm{E}+03$ & $1.51 \mathrm{E}+04$ \\
\hline Pu-238 & NR & NR & $4.27 \mathrm{E}+03$ \\
\hline Pu-239 & NR & NR & $5.15 \mathrm{E}+02$ \\
\hline Tc-99 & NR & NR & $2.88 \mathrm{E}+02$ \\
\hline Total Sr & NR & NR & $8.07 \mathrm{E}+05(\mathrm{dpm} / \mathrm{mL})$ \\
\hline Total Alpha & NR & NR & $3.33 \mathrm{E}+05(\mathrm{dpm} / \mathrm{mL})$ \\
\hline Total Beta & NR & NR & $1.49 \mathrm{E}+08(\mathrm{dpm} / \mathrm{mL})$ \\
\hline \multicolumn{4}{|c|}{ DISSOLUTION RESULTS } \\
\hline Wt\% dissolved & $98.2 \%$ & ND & $93.3 \%$ \\
\hline Solution acid conc. & $2.033 \underline{\mathrm{M}}$ & $1.041 \underline{\mathrm{M}}$ & $0.98 \underline{\mathrm{M}}$ \\
\hline Acid consumption & $0.039 \mathrm{~mol} / \mathrm{gram}$ & $0.041 \mathrm{~mol} / \mathrm{gram}$ & $0.041 \mathrm{~mol} / \mathrm{gram}$ \\
\hline
\end{tabular}

$\mathrm{NR}=$ Analyte not requested

$\mathrm{ND}=$ not determined, Less than indicate result is at or below analytical detection limit. 
A specific list of desired analytes was requested for each dissolver solution resulting from the three dissolution tests. Analytes for each dissolver solution were requested based on their impacts on the performance of separations testing that the solution was going to be used for.

To summarize the three main WM-188/Alumnum Nitrate blend calcine dissolution testing results: 1) between 93 and $98 \mathrm{wt} \%$ of the calcine is expected to be dissolved using testing parameters documented in the preceding tables; 2) acid concentration of final dissolved product used for feedstock solutions to separations experiments can be adjusted by using between 4.5 and $8 \mathrm{M}$ nitric acid dissolvent; and 3) acid consumption values of $0.03-0.04 \mathrm{~mol} / \mathrm{gram}$ calcine can be used to predict final dissolved product acid concentrations if the initial acid concentration of the dissolvent is known.

\section{WM-185/Aluminum Nitrate Blend Dissolution Testing Results}

\section{Batch $\mathrm{Cl}^{-}$dissolution results}

Table 9 presents the experimental data compiled for batch $\mathrm{Cl}^{-}$dissolution including the acid consumed per gram of calcine dissolved.

Table 9. Experimental results for Batch $\mathrm{Cl}^{-}$dissolution.

\begin{tabular}{ccccc}
\hline & $\begin{array}{c}\text { Chloride } \\
\text { concentration }\end{array}$ & $\begin{array}{c}\text { Acid } \\
\text { concentration }\end{array}$ & $\begin{array}{c}\text { Acid } \\
\text { consumption }\end{array}$ & $\begin{array}{c}\text { wt.\% } \\
\text { dissolved }\end{array}$ \\
\hline Batch $\mathrm{Cl}^{-}$ & $5.1 \mathrm{E}+01 \mathrm{ug} / \mathrm{mL}$ & $1.28 \underline{\mathrm{M}}$ & $0.038 \mathrm{~mol} / \mathrm{gram}$ & $88.9 \%$ \\
\hline
\end{tabular}

The batch $\mathrm{Cl}^{-}$dissolution revealed that there was $5.1 \mathrm{E}+01 \mathrm{ug} / \mathrm{mL}$ chloride in $\mathrm{WM}-185 /$ aluminum nitrate blend dissolved solution versus $2.83 \mathrm{E}+02 \mathrm{ug} / \mathrm{mL}$ in the WM-188 blend dissolved solution (see table 8 test \#2). For corrosion considerations, chloride concentration in dissolver solution is important for high level waste equipment design. Further discussion of chloride is outside the scope of this effort.

\section{Calcine characterization results with elemental compositions}

Characterization of the $\mathrm{H}-4$ calcine was the first stage of the material balance testing. Using the previously described fusion method, a full compositional analysis for $\mathrm{H}-4$ calcine was completed. Table 10 presents the elemental fusion results and associated averaged values for $\mathrm{H}-4$ calcine material used for both elemental material balance dissolutions compared with a previously estimated elemental composition of the WM-185/aluminum blend calcine. The previously estimated data represents an estimated composition calculated by O'Brien [8] using actual NWCF calciner feed tank compositions. It should be noted that there is excellent agreement between the averaged values and the previously estimated data.

The elemental composition of the "as received" calcine was determined from fusion data. Elemental compositions were used to estimate compound compositions. Using the summation of weight percentages for each compound, a component material balance around the fusion data was determined. Table 11 contains the calculated compound concentrations and the total sum of compound weight percentages. 
Table 10. Elemental composition of WM-185/aluminum nitrate calcine.

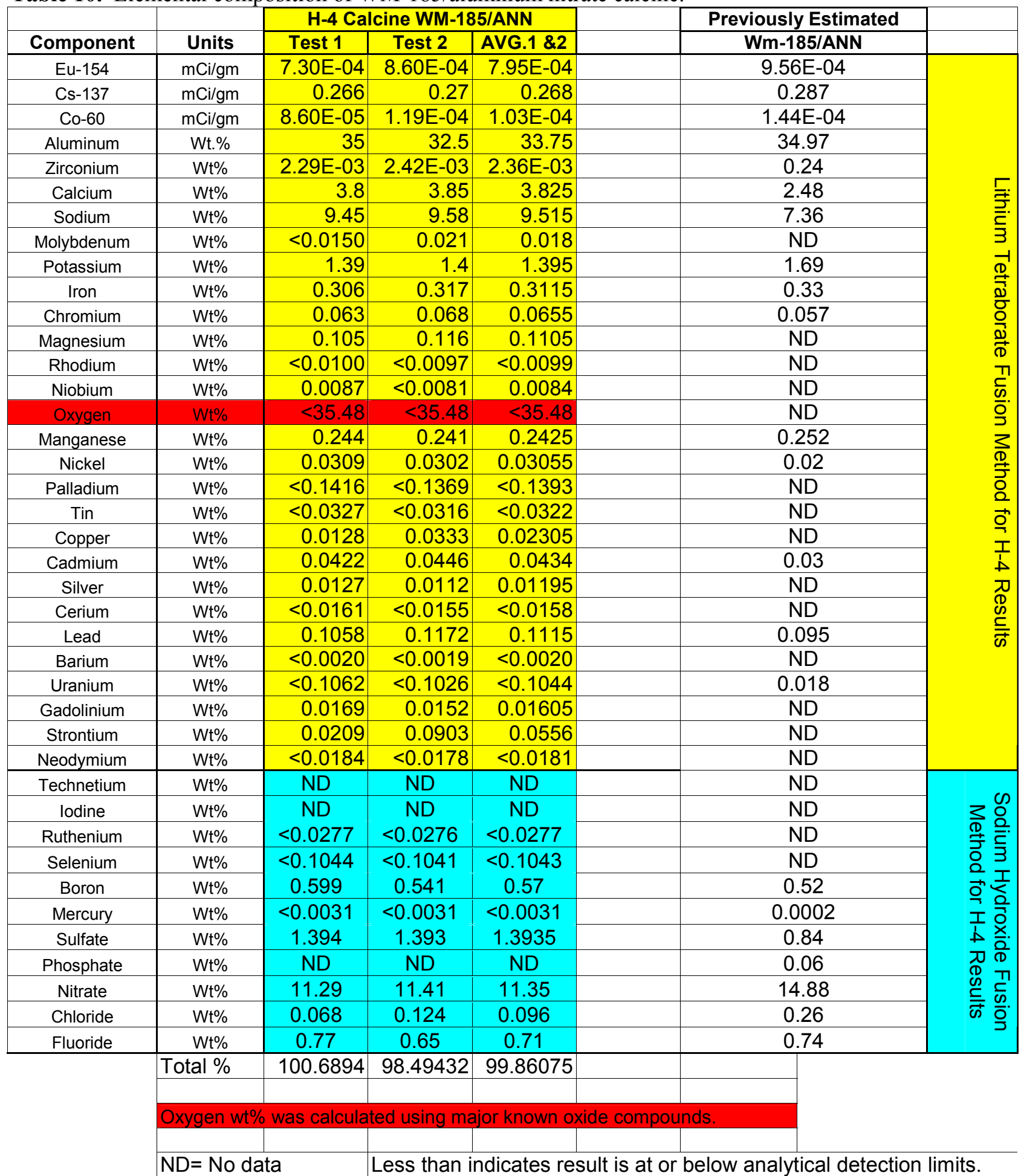


Table 11. Calculated compound concentrations for $\mathrm{H}-4$ calcine.

\begin{tabular}{|c|c|}
\hline Compound & wt. \% in H-4 Calcine \\
\hline $\mathrm{Al}_{2} \mathrm{O}_{3}$ & 63.75 \\
\hline $\mathrm{B}_{2} \mathrm{O}_{3}$ & 1.84 \\
\hline $\mathrm{CaO}$ & 3.4 \\
\hline $\mathrm{CaF}_{2}$ & 1.48 \\
\hline $\mathrm{CaSO}_{4}$ & 2.04 \\
\hline $\mathrm{CdO}$ & 0.05 \\
\hline $\mathrm{Ce}_{2} \mathrm{O}_{3}$ & $<0.02$ \\
\hline $\mathrm{Cr}_{2} \mathrm{O}_{3}$ & 0.1 \\
\hline $\mathrm{HgO}$ & $<0.01$ \\
\hline $\mathrm{Fe}_{2} \mathrm{O}_{3}$ & 0.45 \\
\hline $\mathrm{K}_{2} \mathrm{O}$ & 1.68 \\
\hline $\mathrm{MnO}_{2}$ & 0.38 \\
\hline $\mathrm{Na}_{2} \mathrm{O}$ & 7.2 \\
\hline $\mathrm{NaNO}_{3}$ & 15.7 \\
\hline $\mathrm{NiO}$ & 0.04 \\
\hline $\mathrm{Gd}_{2} \mathrm{O}_{3}$ & 0.02 \\
\hline $\mathrm{PbO}$ or $\mathrm{Pb}_{3} \mathrm{O}_{4}$ & 0.12 \\
\hline $\mathrm{SrO}$ & 0.07 \\
\hline $\mathrm{Cs}_{2} \mathrm{O}$ & $<0.01$ \\
\hline $\mathrm{Mo}_{2} \mathrm{O}_{3}$ & $<0.02$ \\
\hline $\mathrm{MgO}$ & 0.18 \\
\hline $\mathrm{PdO}$ & 0.16 \\
\hline $\mathrm{SnO}$ & $<0.04$ \\
\hline $\mathrm{Cu}_{2} \mathrm{O}$ & 0.03 \\
\hline $\mathrm{Ag}_{2} \mathrm{O}$ & 0.01 \\
\hline $\mathrm{BaO}$ & $<0.01$ \\
\hline $\mathrm{UO}_{2}$ & $<0.12$ \\
\hline $\mathrm{Nd}_{2} \mathrm{O}_{3}$ & $<0.02$ \\
\hline $\mathrm{RuO}_{2}$ & $<0.04$ \\
\hline $\mathrm{SeO}_{2}$ & $<0.15$ \\
\hline $\mathrm{ZrO}_{2}$ & 0.32 \\
\hline tal wt.\% & 99.46 \\
\hline
\end{tabular}

Assumptions: $\mathrm{NO}_{3}^{-}$was assumed to be used up as $\mathrm{NaNO}_{3} ; \mathrm{SO}_{4}{ }^{2-}$ and $\mathrm{F}^{-}$was assumed to be used up as either $\mathrm{CaSO}_{4}$ or $\mathrm{CaF}_{2}$.

\footnotetext{
Less than indicates calculated results use concentrations at or below analytical detection limits.
} 


\section{WM-185/aluminum nitrate blend calcine dissolutions}

Two dissolution experiments were performed using the WM-185 /aluminum nitrate blend. The dissolution parameters were identical for both experiments. The first dissolution was different in that radioactive technetium and iodine were spiked in the initial calcine solids and the UDS solids prior to being fused for compositional analysis. The purpose of the radioactive spikes was to increase concentrations to measure recovery or determine the fate of the species during performance of the fusion methods. This spike procedure provided inconclusive evidence as to the fate of the elements because the spike isotopes chosen were the same isotopes as were found to be in the calcine.

Table 12 includes the experimental data received from the two dissolutions. The data includes the masses used to calculate weight percent dissolved.

Table 12. WM-185/ aluminum nitrate experimental dissolution data.

\begin{tabular}{c|ccc} 
Experiment & $\begin{array}{c}\text { Initial } \\
\text { calcine } \\
\text { weight (g) }\end{array}$ & $\begin{array}{c}\text { UDSweight } \\
\text { (g) }\end{array}$ & $\begin{array}{c}\text { Weight \% } \\
\text { dissolution }\end{array}$ \\
\hline Dissolution \#1 & 10.001 & 0.541 & $94.6 \%$ \\
& & & \\
Dissolution \#2 & 10.005 & 0.554 & $95.5 \%$
\end{tabular}

The elemental composition results for the dissolved solution were reported in units elemental concentrations of dissolved constituents per gram of calcine added to the nitric acid dissolvent. The elemental compositions of the UDS were also required to determine what percentage of each element was not dissolved in nitric acid. Analyses of the two scrub solutions were requested to determine if volatile species were scrubbed from the dissolver off-gas. Table 13A provides the elemental compositions of the final dissolved solutions and Table 13B provides elemental compositions of the UDS and Off-gas solutions. 
Table 13A. Elemental composition of WM-185 blend dissolved solutions.

\begin{tabular}{|c|c|c|c|}
\hline \multirow[b]{2}{*}{ Component } & \multirow[b]{2}{*}{ Units } & \multicolumn{2}{|c|}{ Dissolved Solutions } \\
\hline & & Diss. \#1 & Diss. \#2 \\
\hline Eu-154 & dps dissolved/g calcine & $2.23 E+04$ & $2.49 E+04$ \\
\hline Cs-137 & dps dissolved/g calcine & $1.04 \mathrm{E}+07$ & $1.01 \mathrm{E}+07$ \\
\hline Co-60 & dps dissolved/g calcine & $2.410 E+03$ & $3.009 E+03$ \\
\hline Technetium & dps dissolved/g calcine & 240424 & ND \\
\hline lodine & dps dissolved/g calcine & ND & ND \\
\hline Aluminum & $\mathrm{mg}$ dissolved/kg calcine & $3.55 E+05$ & $3.25 E+05$ \\
\hline Zirconium & $\mathrm{mg}$ dissolved/kg calcine & 1.869E+03 & 1.837E+03 \\
\hline Calcium & $\mathrm{mg}$ dissolved/kg calcine & 3.67E+04 & $3.65 E+04$ \\
\hline Sodium & $\mathrm{mg}$ dissolved/kg calcine & $1.068 \mathrm{E}+05$ & $1.022 \mathrm{E}+05$ \\
\hline Molybdenum & $\mathrm{mg}$ dissolved/kg calcine & $7.324 \mathrm{E}+01$ & $7.348 \mathrm{E}+01$ \\
\hline Potassium & $\mathrm{mg}$ dissolved/kg calcine & 1.410E+04 & 1.460E+04 \\
\hline Iron & $\mathrm{mg}$ dissolved/kg calcine & $2.612 E+03$ & $2.601 \mathrm{E}+03$ \\
\hline Chromium & $\mathrm{mg}$ dissolved/kg calcine & $5.270 \mathrm{E}+02$ & $5.178 E+02$ \\
\hline Magnesium & $\mathrm{mg}$ dissolved/kg calcine & $9.394 \mathrm{E}+02$ & $9.604 E+02$ \\
\hline Rhodium & $\mathrm{mg}$ dissolved/kg calcine & $<2.02$ & $<2.02$ \\
\hline Niobium & $\mathrm{mg}$ dissolved/kg calcine & $2.460 \mathrm{E}+00$ & $1.950 \mathrm{E}+00$ \\
\hline Manganese & $\mathrm{mg}$ dissolved/kg calcine & $2.233 E+03$ & $2.277 E+03$ \\
\hline Nickel & $\mathrm{mg}$ dissolved/kg calcine & $2.201 \mathrm{E}+02$ & $2.149 E+02$ \\
\hline Palladium & $\mathrm{mg}$ dissolved/kg calcine & $<28.33$ & $<28.31$ \\
\hline Tin & $\mathrm{mg}$ dissolved/kg calcine & $7.850 E+00$ & $1.746 \mathrm{E}+01$ \\
\hline Copper & $\mathrm{mg}$ dissolved/kg calcine & 1.054E+02 & 1.070E+02 \\
\hline Cadmium & $\mathrm{mg}$ dissolved/kg calcine & $3.488 E+02$ & $3.522 E+02$ \\
\hline Silver & $\mathrm{mg}$ dissolved/kg calcine & $<0.44$ & $<0.44$ \\
\hline Cerium & $\mathrm{mg}$ dissolved/kg calcine & $1.350 \mathrm{E}+01$ & $1.419 E+01$ \\
\hline Lead & $\mathrm{mg}$ dissolved/kg calcine & $9.140 \mathrm{E}+02$ & $9.082 E+02$ \\
\hline Barium & $\mathrm{mg}$ dissolved/kg calcine & 1.247E+01 & 1.350E+01 \\
\hline Uranium & $\mathrm{mg}$ dissolved/kg calcine & $2.606 \mathrm{E}+02$ & $2.401 \mathrm{E}+02$ \\
\hline Gadolinium & $\mathrm{mg}$ dissolved/kg calcine & 1.713E+02 & 1.668E+02 \\
\hline Strontium & $\mathrm{mg}$ dissolved/kg calcine & 1.449E+02 & 1.440E+02 \\
\hline Neodymium & $\mathrm{mg}$ dissolved/kg calcine & 2.908E+01 & 2.953E+01 \\
\hline Ruthenium & $\mathrm{mg}$ dissolved/kg calcine & $5.567 E+01$ & $5.224 E+01$ \\
\hline Selenium & $\mathrm{mg}$ dissolved/kg calcine & $<6.09$ & 10.79 \\
\hline Boron & $\mathrm{mg}$ dissolved/kg calcine & $6.38 E+03$ & $5.72 E+03$ \\
\hline Mercury & $\mathrm{mg}$ dissolved/kg calcine & 19 & 15 \\
\hline Sulfate & $\mathrm{mg}$ dissolved/kg calcine & $9.500 \mathrm{E}+03$ & $9.900 \mathrm{E}+03$ \\
\hline Nitrate & $\mathrm{mg}$ dissolved/kg calcine & ND & ND \\
\hline Chloride & $\mathrm{mg}$ dissolved/kg calcine & $<1200$ & 1.010E+03 \\
\hline Fluoride & $\mathrm{mg}$ dissolved/kg calcine & 1.600E+04 & $3.900 E+03$ \\
\hline
\end{tabular}

Less than indicates result is at or below analytical detection limit. 
Table 13B. Elemental composition of WM-185 blend UDS and Off-Gas solutions.

\begin{tabular}{|c|c|c|c|c|c|c|c|c|c|}
\hline \multicolumn{4}{|c|}{ Undissolved Solids } & \multicolumn{6}{|c|}{ Off-Gas } \\
\hline Component & Units & UDS \#1 & UDS \#2 & Component & Units & CS \#1 & AS \#1 & CS \#2 & AS \#2 \\
\hline Eu-154 & dps/g UDS & $4.115 \mathrm{E}+04$ & $3.995 \mathrm{E}+04$ & Eu-154 & dps/g calcine & BDL & BDL & $\mathrm{BDL}$ & $\mathrm{BDL}$ \\
\hline Cs-137 & dps/g UDS & $2.880 \mathrm{E}+05$ & $2.950 \mathrm{E}+05$ & Cs-137 & dps/g calcine & 59 & 61.2 & 33.1 & 55.5 \\
\hline Co-60 & $\mathrm{dps} / \mathrm{g}$ UDS & $4.769 \mathrm{E}+03$ & $5.792 \mathrm{E}+03$ & Co-60 & dps/g calcine & BDL & BDL & BDL & BDL \\
\hline Technetium & $\mathrm{dps} / \mathrm{g}$ UDS & 2826.2 & 1639.2 & Technetium & $\mathrm{dps} / \mathrm{g}$ calcine & 1.41 & ND & 1.8 & ND \\
\hline lodine & dps/g UDS & ND & 100.5 & Ruthenium & $\mathrm{N} / \mathrm{A}$ & $<5.50$ & ND & $<5.50$ & ND \\
\hline Aluminum & $\mathrm{mg} / \mathrm{kg}$ UDS & $5.18 \mathrm{E}+05$ & $2.84 \mathrm{E}+05$ & Mercury & $\mathrm{mg} / \mathrm{kg}$ calcine & $<0.31$ & $<0.31$ & $<0.31$ & $<0.31$ \\
\hline Zirconium & $\mathrm{mg} / \mathrm{kg}$ UDS & $9.557 \mathrm{E}+03$ & $1.595 \mathrm{E}+04$ & Nitrate & $\mathrm{mg} / \mathrm{kg}$ calcine & $<0.50$ & ND & $<0.50$ & ND \\
\hline Calcium & $\mathrm{mg} / \mathrm{kg}$ UDS & $6.15 E+03$ & $6.40 \mathrm{E}+03$ & Chloride & $\mathrm{mg} / \mathrm{kg}$ calcine & $<0.12$ & $<0.12$ & $<0.12$ & $<0.12$ \\
\hline Sodium & $\mathrm{mg} / \mathrm{kg}$ UDS & $4.350 \mathrm{E}+04$ & $3.160 \mathrm{E}+04$ & & & & & & \\
\hline Molybdenum & $\mathrm{mg} / \mathrm{kg}$ UDS & $<147.40$ & $<151.78$ & & & \multirow{3}{*}{\multicolumn{4}{|c|}{$\begin{array}{l}\text { BDL= Below detection limit } \\
\text { ND= No data or not determined } \\
\text { CS= Caustic scrub solution } \\
\text { AS= Acidic scrub solution }\end{array}$}} \\
\hline Potassium & $\mathrm{mg} / \mathrm{kg}$ UDS & $3.750 \mathrm{E}+04$ & $3.850 \mathrm{E}+04$ & & & & & & \\
\hline Iron & $\mathrm{mg} / \mathrm{kg}$ UDS & $4.560 \mathrm{E}+03$ & $6.821 \mathrm{E}+03$ & & & & & & \\
\hline Chromium & $\mathrm{mg} / \mathrm{kg}$ UDS & $5.331 \mathrm{E}+02$ & $5.853 E+02$ & & & & & & \\
\hline Magnesium & $\mathrm{mg} / \mathrm{kg}$ UDS & $1.902 \mathrm{E}+03$ & $1.828 \mathrm{E}+03$ & & & & & & \\
\hline Rhodium & $\mathrm{mg} / \mathrm{kg}$ UDS & $<96.92$ & $<99.80$ & & & & & & \\
\hline Niobium & $\mathrm{mg} / \mathrm{kg}$ UDS & $9.591 \mathrm{E}+01$ & $9.481 \mathrm{E}+02$ & & & & & & \\
\hline Manganese & $\mathrm{mg} / \mathrm{kg}$ UDS & $3.752 \mathrm{E}+03$ & $4.329 \mathrm{E}+03$ & & & & & & \\
\hline Nickel & $\mathrm{mg} / \mathrm{kg}$ UDS & $4.331 \mathrm{E}+02$ & $1.495 \mathrm{E}+03$ & & & & & & \\
\hline Palladium & $\mathrm{mg} / \mathrm{kg}$ UDS & $<1361.97$ & $<1402.43$ & & & & & & \\
\hline Tin & $\mathrm{mg} / \mathrm{kg}$ UDS & $<313.99$ & $2.414 \mathrm{E}+03$ & & & & & & \\
\hline Copper & $\mathrm{mg} / \mathrm{kg}$ UDS & $1.969 \mathrm{E}+02$ & $5.697 \mathrm{E}+02$ & & & & & & \\
\hline Cadmium & $\mathrm{mg} / \mathrm{kg}$ UDS & $2.151 \mathrm{E}+02$ & $2.661 \mathrm{E}+02$ & & & & & & \\
\hline Silver & $\mathrm{mg} / \mathrm{kg}$ UDS & $1.121 \mathrm{E}+02$ & $1.185 \mathrm{E}+02$ & & & & & & \\
\hline Cerium & $\mathrm{mg} / \mathrm{kg}$ UDS & $<154.47$ & $<159.06$ & & & & & & \\
\hline Lead & $\mathrm{mg} / \mathrm{kg}$ UDS & $5.008 \mathrm{E}+02$ & $6.331 \mathrm{E}+02$ & & & & & & \\
\hline Barium & $\mathrm{mg} / \mathrm{kg}$ UDS & $1.121 \mathrm{E}+02$ & $1.258 \mathrm{E}+02$ & & & & & & \\
\hline Uranium & $\mathrm{mg} / \mathrm{kg}$ UDS & $<1020.72$ & $<1051.04$ & & & & & & \\
\hline Gadolinium & $\mathrm{mg} / \mathrm{kg}$ UDS & $2.403 E+02$ & $2.703 \mathrm{E}+02$ & & & & & & \\
\hline Strontium & $\mathrm{mg} / \mathrm{kg}$ UDS & $1.999 \mathrm{E}+02$ & $2.755 \mathrm{E}+02$ & & & & & & \\
\hline Neodymium & $\mathrm{mg} / \mathrm{kg}$ UDS & $<176.68$ & $<181.93$ & & & & & & \\
\hline Ruthenium & $\mathrm{mg} / \mathrm{kg}$ UDS & $<268.49$ & $<271.13$ & & & & & & \\
\hline Selenium & $\mathrm{mg} / \mathrm{kg}$ UDS & $<1013.51$ & $<1023.45$ & & & & & & \\
\hline Boron & $\mathrm{mg} / \mathrm{kg}$ UDS & $<472.43$ & $<477.06$ & & & & & & \\
\hline Mercury & $\mathrm{mg} / \mathrm{kg}$ UDS & 1.390E-01 & $6.200 \mathrm{E}-02$ & & & & & & \\
\hline Sulfate & $\mathrm{mg} / \mathrm{kg}$ UDS & 1.957E-01 & 1.245E-01 & & & & & & \\
\hline Nitrate & $\mathrm{mg} / \mathrm{kg}$ UDS & $1.710 \mathrm{E}+00$ & $1.520 \mathrm{E}+00$ & & & & & & \\
\hline Chloride & $\mathrm{mg} / \mathrm{kg}$ UDS & 1.300E-02 & 3.000E-02 & & & & & & \\
\hline Fluoride & $\mathrm{mg} / \mathrm{kg}$ UDS & $<1.57$ & $1.800 \mathrm{E}+00$ & & & & & & \\
\hline
\end{tabular}




\section{Elemental material balance around dissolution of WM-185/aluminum nitrate blend}

Material balance calculations were completed for each stable element and radioactive specie that had been analyzed for in Table 13A. Each elemental material balance calculation was found by taking the sum of concentrations of each element in the effluent section of the dissolution system and dividing this sum by the concentration of the analyzed element in the initial calcine fusion. The following equation was used to determine elemental material balance for each element.

$$
\% M B=\frac{C O N C . \text { diss.sol }}{+C O N C_{. \text {UDS. }}+C O N C . \text { ofF }- \text { Gas }} \times 100 \%
$$

Unit conversions were needed to ensure agreement of terms throughout the calculation. The effluent sections of the dissolution system consisted of the dissolved solution, UDS, and off-gas in the case of volatile species. Table 14 includes the material balance results calculated for the H-4 dissolution experiment. Table 14 does not include material balance calculations for all stable elements because analytical results received were at or below detection limits. (Refer to Tables 10 and 11). Appendix B provides all of the material balance dissolution testing raw data as received from the analytical department.

Table 14. Elemental material balance for WM-185 blend calcine dissolution.

\begin{tabular}{|l|c|c|c|}
\hline \multicolumn{3}{|c|}{ Elemental Material Balance } \\
\hline \multicolumn{1}{|c|}{ Element } & Dissolution \#1 & & Dissolution \#2 \\
\hline Eu-154 & 94.45 & & 85.36 \\
\hline Cs-137 & 109.97 & & 101.70 \\
\hline Co-60 & 87.22 & & 73.85 \\
\hline Technetium & 157.81 & & 100.04 \\
\hline lodine & $\mathrm{ND}$ & & 101.23 \\
\hline Aluminum & 107.88 & & 104.81 \\
\hline Zirconium & 103.98 & & 112.16 \\
\hline Calcium & 97.45 & & 95.72 \\
\hline Sodium & 115.50 & & 108.49 \\
\hline Potassium & 116.01 & & 119.41 \\
\hline Iron & 93.30 & & 93.88 \\
\hline Chromium & 87.67 & & 80.64 \\
\hline Magnesium & 99.63 & & 91.30 \\
\hline Manganese & 99.97 & & 104.34 \\
\hline Lead & 88.95 & & 80.46 \\
\hline Gadolinium & 109.04 & & 119.50 \\
\hline Boron & 107.01 & & 106.22 \\
\hline Sulfate & 68.13 & & 71.09 \\
\hline
\end{tabular}

The material balance results for the major calcine constituents are well within analytical error ranges incurred during analyses. The results validate analytical procedures used in determining compositional analysis for both liquid and solid fractions of the dissolution experiment. 


\section{CONCLUSIONS}

The weight percent dissolved for both WM-188/aluminum nitrate blend calcine and the WM-185/aluminum nitrate blend calcine is expected to reach 90-95 wt\% using 5-8 $\underline{\mathrm{M}}$ nitric acid at a 1 gram calcine to $10 \mathrm{mLs}$ acid ratio, at boiling temperature for 1-1.5 hours.

Spiking radioactive technetium and iodine to improve measurement of recovery of volatile species did not provide desired additional useful information.

Acid consumption for each blend dissolution testing ranged between 0.03-0.04 mols of acid consumed per gram of calcine dissolved. The final acid concentration of the dissolved solution can be adjusted to meet separations experimental testing requests.

The material balance results for the H-4 dissolution experiments validate analytical procedures used to determine compositions of both liquid and solid fractions of the dissolution experiment. 


\section{REFERENCES}

1. J. R. Berreth, "Inventories and Properties of ICPP Calcines High-Level Waste", WINCO-1050, February 1988.

2. R. S. Herbst, D S. Fryer, K. N. Brewer, C. K. Johnson, and T. A. Todd, "Experimental Results: Pilot Plant Calcine Dissolution and Liquid Feed Stability Study", INEL-95/0097, February 1995.

3. K. N. Brewer, R. S. Herbst, T. J. Tranter, A. L. Olson, T. A. Todd, "Dissolution of Two NWCF Calcines: Extent of Dissolution and Characterization of Undissolved Solids", INEL-95/0098, February 1995.

4. K. N. Brewer, A. L. Olson, W. S. Roesener, J. L. Tonso, "Experimental Results of Calcine Dissolution Studies Performed During FY-94,95”, INEEL/EXT-97-01192, September 1997.

5. R. S. Herbst, T. G. Garn, "Dissolution Studies With Pilot Plant and Actual INTEC Calcines", INEEL/EXT-99-00325, April 1999.

6. M. D. Staiger, "Calcine Waste Storage at the Idaho Nuclear Technology and Engineering Center", INEEL/EXT-98-00455, June 1999.

7. B. J. Newby, B. H. O'Brien, "Summary of Waste Calcination At the Idaho Nuclear Technology and Engineering Center", INEEL/EXT-2000-01206, October 2000.

8. B. H. O’Brien, Idaho National Engineering and Environmental Laboratory, personal communication.

9. U.S. Department of Energy, "Idaho High-Level Waste and Facilities Disposition Draft Environmental Impact Statement”, DOE/EIS-0287D, December 1999. 
Appendix A

Dissolution Procedure 


\section{APPENDIX A}

\section{Dissolution Procedure}

\section{Procedure For Dissolution Of Radioactive Calcine Solids}

\section{Equipment:}

1. Ensure the following equipment is assembled and operational.

-Reflux condenser connected to DI water supply

-Dissolution Vessel with appropriate stirbar and glass stoppers

-Magnetic Stirplate/Hotplate

-Balance

$-500 \mathrm{~mL}$ Filter Unit with $0.45 \mu \mathrm{m}$ filter

-Vacuum Pump with tubing and hookup

-Weighing Boats/Cups and necessary accessories

-Ringstand to support reflux condenser

2. Retrieve calcine from storage location.

\section{Procedure:}

1. Insert stirbar in dissolver vessel and place dissolver on hotplate then insert condenser (supported by ringstand) in top of dissolver.

a. Researcher will provide technician/analyst with dissolution parameters to be used for dissolution.

b. Parameters: Nitric acid concentration M, $\%$ product to $\%$ fines ratio calcine weight to acid volume $\mathrm{gms} / \mathrm{mL}$, dissolution time hrs.

Note: $\%$ product to $\%$ fines ratio is needed for pilot plant calcine dissolution only.

2. Tare weigh boat/cup on balance and record weight. gms

3. Re-zero balance then carefully pour calcine into weighing boat/cup until balance indicates weight as directed by researcher. Record actual weight of calcine. gms.

4. Slowly add calcine to dissolver.

(Note: Some experiments may require calcine to be added to an already heated acid, in this case this step will be performed after step 7.)

5. Add appropriate volume of nitric acid to dissolver. (Calcine weight $\mathrm{x} \mathrm{mL}$ acid volume $=\mathrm{mLs}$ of nitric acid required.) Volume added $\mathrm{mLs}$. Place stopper in calcine addition port and ensure vessel is sealed.

6. Start water flow through condenser and record time.

7. Turn heat on to hotplate. Begin stirring, stir at a rate that just moves solution in a circular motion but doesn't slosh solution up on walls of dissolution vessel. 
8. Observe solution during heatup. When solution reaches temperature record time

Maintain solution temperature for dissolution time recorded above. If directed by experimenter, pull a sample of the heated solution for kinetic study purposes.

9. At the end of dissolution time, shut off heat to hotplate. Record time Continue stirring for 1 hour to assist cooling of solution. Continue water flow through condenser to prevent evaporation of solution during cool down.

10. Allow to cool for 1 hour, shut down stirring and water flow to condenser. Record time to calculate volume of water added to PEW through condenser.

11. Carefully remove condenser from dissolver vessel. Insert glass stopper to top of dissolver and transport vessel to window with vacuum pump capabilities. Allow settling for a minimum of 12 hours before filtering solution.

12. Prepare to filter solution. Place filtration unit on balance and record tare weight. gms

13. Assemble filtration unit and attach to vacuum pump. Energize vacuum pump.

14. Carefully decant solution from dissolver vessel into filtration unit leaving very small volume of solution with undissolved solids (UDS) in dissolver vessel. When solution has passed through filter and captured in bottom of filtration unit, transfer solution into an appropriately labeled sample bottle for analysis.

15. Reassemble filtration unit and pour remainder of UDS with solution into filtration unit by carefully swishing solution in a circular motion before pouring rapidly into filtration unit. Rinse dissolver vessel as necessary to remove all solids from dissolver vessel to filtration unit.

16. After all rinse solution has passed through filter, pour a small volume of Isopropanol (15 mLs) onto solids to assist with drying of solids. Allow solids to completely dry under vacuum. Deenergize vacuum pump.

17. Disassemble filtration unit and reweigh top portion of unit on balance. If balance reading does not stabilize, solids need more time to dry. When reading stabilizes, record weight. gms

18. Calculate percent dissolution: Subtract tare weight of filter (step 13) from final weight of filter with solids (step 18), this will be weight of UDS. Subtract UDS weight from initial mass of calcine added to dissolution vessel (step 3) then divide this number by initial mass of calcine added (step 3) and multiply by $100 \%$ to determine percent dissolution. Record percent dissolution. $\%$

$$
\begin{aligned}
& \text { (Step 13) } \\
& \text { gms - (Step 18) } \\
& \text { gms }= \\
& (\text { Step 3)__ gms }-(\text { UDS wt. })=\ldots \text { grams dissolved } \\
& \% \text { Dissolution }=\frac{\text { gramsdissolved }}{(\text { Step } 3)} \times 100 \%
\end{aligned}
$$
UDS wt.

19. Thoroughly rinse dissolver vessel as necessary for future use. Disassemble experimental setup as directed by researcher. Clean work areas as needed. 
Appendix B

H-4 Calcine Material Balance Dissolution Raw Analytical Data 


\section{APPENDIX B}

\section{H-4 Calcine Material Balance Dissolution Raw Analytical Data}

\section{Initial Calcine Data}

\begin{tabular}{|c|c|c|c|c|c|c|c|c|}
\hline units & Component & CalcLTF-1 & CalcLTF-2 & CalcNH-1A & CalcNH-1B & CalcNH-2A & CalcNH-2B & Calc (AVG) \\
\hline $\mathrm{dps} / \mathrm{mL}$ & Eu-154 & 54 & 66 & 48.7 & 42.9 & 38.4 & 44.4 & 49.07 \\
\hline $\mathrm{dps} / \mathrm{mL}$ & Cs-137 & $1.97 E+04$ & $2.068 \mathrm{E}+04$ & $2.07 E+04$ & $2.05 E+04$ & $2.11 \mathrm{E}+04$ & $1.84 \mathrm{E}+04$ & $2.018 \mathrm{E}+04$ \\
\hline $\mathrm{dps} / \mathrm{mL}$ & Co-60 & 6.36 & 9.1 & 5.54 & 7.15 & 2.31 & 5.53 & 6.00 \\
\hline $\mathrm{mg} / \mathrm{kg}$ & Aluminum & $3.50 \mathrm{E}+05$ & $3.25 \mathrm{E}+05$ & N/A & N/A & N/A & N/A & $3.375 \mathrm{E}+05$ \\
\hline $\mathrm{mg} / \mathrm{kg}$ & Zirconium & $2.294 \mathrm{E}+03$ & $2.420 \mathrm{E}+03$ & $\mathrm{~N} / \mathrm{A}$ & $\mathrm{N} / \mathrm{A}$ & $\mathrm{N} / \mathrm{A}$ & $\mathrm{N} / \mathrm{A}$ & $2.357 \mathrm{E}+03$ \\
\hline $\mathrm{mg} / \mathrm{kg}$ & Calcium & $3.80 \mathrm{E}+04$ & $3.85 \mathrm{E}+04$ & $\mathrm{~N} / \mathrm{A}$ & $\mathrm{N} / \mathrm{A}$ & N/A & $\mathrm{N} / \mathrm{A}$ & $3.825 \mathrm{E}+04$ \\
\hline $\mathrm{Wt} \%$ & Sodium & 9.45 & 9.58 & $\mathrm{~N} / \mathrm{A}$ & N/A & $\mathrm{N} / \mathrm{A}$ & $\mathrm{N} / \mathrm{A}$ & 9.52 \\
\hline $\mathrm{mg} / \mathrm{kg}$ & Molybdenum & $<153.30$ & 208.99 & $\mathrm{~N} / \mathrm{A}$ & $\mathrm{N} / \mathrm{A}$ & N/A & $\mathrm{N} / \mathrm{A}$ & 181.15 \\
\hline $\mathrm{Wt} \%$ & Potassium & 1.39 & 1.4 & $\mathrm{~N} / \mathrm{A}$ & $\mathrm{N} / \mathrm{A}$ & $\mathrm{N} / \mathrm{A}$ & $\mathrm{N} / \mathrm{A}$ & 1.40 \\
\hline $\mathrm{mg} / \mathrm{kg}$ & Iron & $3.06 \mathrm{E}+03$ & $3.17 E+03$ & $\mathrm{~N} / \mathrm{A}$ & N/A & $\mathrm{N} / \mathrm{A}$ & $\mathrm{N} / \mathrm{A}$ & $3.118 \mathrm{E}+03$ \\
\hline $\mathrm{mg} / \mathrm{kg}$ & Chromium & 634.2 & 681.74 & N/A & N/A & $\mathrm{N} / \mathrm{A}$ & $\mathrm{N} / \mathrm{A}$ & 657.97 \\
\hline $\mathrm{mg} / \mathrm{kg}$ & Magnesium & $1.046 \mathrm{E}+03$ & $1.162 \mathrm{E}+03$ & $\mathrm{~N} / \mathrm{A}$ & $\mathrm{N} / \mathrm{A}$ & $\mathrm{N} / \mathrm{A}$ & $\mathrm{N} / \mathrm{A}$ & 1.104E+03 \\
\hline $\mathrm{mg} / \mathrm{kg}$ & Rhodium & $<100.80$ & $<97.39$ & $\mathrm{~N} / \mathrm{A}$ & $\mathrm{N} / \mathrm{A}$ & N/A & $\mathrm{N} / \mathrm{A}$ & 99.10 \\
\hline $\mathrm{mg} / \mathrm{kg}$ & Niobium & 87.15 & $<81.16$ & N/A & $\mathrm{N} / \mathrm{A}$ & N/A & $\mathrm{N} / \mathrm{A}$ & 84.16 \\
\hline $\mathrm{mg} / \mathrm{kg}$ & Manganese & $2.44 \mathrm{E}+03$ & $2.41 \mathrm{E}+03$ & $\mathrm{~N} / \mathrm{A}$ & $\mathrm{N} / \mathrm{A}$ & N/A & N/A & $2.423 \mathrm{E}+03$ \\
\hline $\mathrm{mg} / \mathrm{kg}$ & Nickel & 308.7 & 302.32 & $\mathrm{~N} / \mathrm{A}$ & $\mathrm{N} / \mathrm{A}$ & N/A & $\mathrm{N} / \mathrm{A}$ & 305.51 \\
\hline $\mathrm{mg} / \mathrm{kg}$ & Palladium & $1.416 \mathrm{E}+03$ & $1.369 E+03$ & $\mathrm{~N} / \mathrm{A}$ & $\mathrm{N} / \mathrm{A}$ & $\mathrm{N} / \mathrm{A}$ & $\mathrm{N} / \mathrm{A}$ & $1.393 E+03$ \\
\hline $\mathrm{mg} / \mathrm{kg}$ & Tin & $<326.55$ & $<315.51$ & N/A & N/A & N/A & $\mathrm{N} / \mathrm{A}$ & 321.03 \\
\hline $\mathrm{mg} / \mathrm{kg}$ & Copper & 128.1 & 332.75 & $\mathrm{~N} / \mathrm{A}$ & $\mathrm{N} / \mathrm{A}$ & N/A & $\mathrm{N} / \mathrm{A}$ & 230.43 \\
\hline $\mathrm{mg} / \mathrm{kg}$ & Cadmium & 422.1 & 446.4 & $\mathrm{~N} / \mathrm{A}$ & N/A & $\mathrm{N} / \mathrm{A}$ & $\mathrm{N} / \mathrm{A}$ & 434.25 \\
\hline $\mathrm{mg} / \mathrm{kg}$ & Silver & 127.05 & 111.59 & N/A & N/A & $\mathrm{N} / \mathrm{A}$ & $\mathrm{N} / \mathrm{A}$ & 119.32 \\
\hline $\mathrm{mg} / \mathrm{kg}$ & Cerium & $<160.65$ & $<155.22$ & $\mathrm{~N} / \mathrm{A}$ & N/A & $\mathrm{N} / \mathrm{A}$ & $\mathrm{N} / \mathrm{A}$ & 157.94 \\
\hline $\mathrm{mg} / \mathrm{kg}$ & Lead & $1.058 E+03$ & $1.172 E+03$ & $\mathrm{~N} / \mathrm{A}$ & $\mathrm{N} / \mathrm{A}$ & $\mathrm{N} / \mathrm{A}$ & $\mathrm{N} / \mathrm{A}$ & $1.115 \mathrm{E}+03$ \\
\hline $\mathrm{mg} / \mathrm{kg}$ & Barium & $<19.95$ & $<19.28$ & $\mathrm{~N} / \mathrm{A}$ & $\mathrm{N} / \mathrm{A}$ & $\mathrm{N} / \mathrm{A}$ & $\mathrm{N} / \mathrm{A}$ & 19.62 \\
\hline $\mathrm{mg} / \mathrm{kg}$ & Uranium & $1.062 \mathrm{E}+03$ & $1.026 \mathrm{E}+03$ & $\mathrm{~N} / \mathrm{A}$ & N/A & $\mathrm{N} / \mathrm{A}$ & $\mathrm{N} / \mathrm{A}$ & $1.044 \mathrm{E}+03$ \\
\hline $\mathrm{mg} / \mathrm{kg}$ & Gadolinium & 169.05 & 152.17 & $\mathrm{~N} / \mathrm{A}$ & $\mathrm{N} / \mathrm{A}$ & $\mathrm{N} / \mathrm{A}$ & $\mathrm{N} / \mathrm{A}$ & 160.61 \\
\hline $\mathrm{mg} / \mathrm{kg}$ & Strontium & 208.95 & 902.9 & $\mathrm{~N} / \mathrm{A}$ & $N / A$ & $\mathrm{~N} / \mathrm{A}$ & $\mathrm{N} / \mathrm{A}$ & 555.93 \\
\hline $\mathrm{mg} / \mathrm{kg}$ & Neodimium & $<183.75$ & $<177.54$ & N/A & N/A & $\mathrm{N} / \mathrm{A}$ & $\mathrm{N} / \mathrm{A}$ & 180.65 \\
\hline $\mathrm{dps} / \mathrm{mL}$ & Technetium & N/A & N/A & 0.528 & 482.05 & $\mathrm{~N} / \mathrm{A}$ & $\mathrm{N} / \mathrm{A}$ & ND \\
\hline $\mathrm{dps} / \mathrm{mL}$ & lodine & N/A & $\mathrm{N} / \mathrm{A}$ & ND & 0.947 & $\mathrm{~N} / \mathrm{A}$ & $\mathrm{N} / \mathrm{A}$ & 0.947 \\
\hline $\mathrm{mg} / \mathrm{kg}$ & Ruthenium & N/A & $\mathrm{N} / \mathrm{A}$ & $<276.55$ & $<275.86$ & $\mathrm{~N} / \mathrm{A}$ & $\mathrm{N} / \mathrm{A}$ & 276.205 \\
\hline $\mathrm{mg} / \mathrm{kg}$ & Selenium & N/A & $\mathrm{N} / \mathrm{A}$ & $<1043.92$ & $<1041.32$ & $\mathrm{~N} / \mathrm{A}$ & $\mathrm{N} / \mathrm{A}$ & 1042.62 \\
\hline $\mathrm{mg} / \mathrm{kg}$ & Boron & $\mathrm{N} / \mathrm{A}$ & $\mathrm{N} / \mathrm{A}$ & $5.99 \mathrm{E}+03$ & $5.41 \mathrm{E}+03$ & $\mathrm{~N} / \mathrm{A}$ & $\mathrm{N} / \mathrm{A}$ & 5700 \\
\hline WT\% & Mercury & $\mathrm{N} / \mathrm{A}$ & $\mathrm{N} / \mathrm{A}$ & $<0.0031$ & $<0.0031$ & $\mathrm{~N} / \mathrm{A}$ & $\mathrm{N} / \mathrm{A}$ & 0.0031 \\
\hline WT\% & Sulfate & N/A & $\mathrm{N} / \mathrm{A}$ & 1.39429 & 1.39264 & $\mathrm{~N} / \mathrm{A}$ & $\mathrm{N} / \mathrm{A}$ & 1.393465 \\
\hline WT\% & Nitrate & $\mathrm{N} / \mathrm{A}$ & $\mathrm{N} / \mathrm{A}$ & 11.29 & 11.41 & $\mathrm{~N} / \mathrm{A}$ & $\mathrm{N} / \mathrm{A}$ & 11.35 \\
\hline WT\% & Chloride & N/A & N/A & 0.068 & 0.124 & N/A & N/A & 0.096 \\
\hline WT\% & Flouride & $\mathrm{N} / \mathrm{A}$ & $\mathrm{N} / \mathrm{A}$ & $N / A$ & N/A & 0.77 & 0.65 & 0.71 \\
\hline
\end{tabular}

Less than indicates results are at or below analytical detection limits. 


\section{UDS data}

\begin{tabular}{|c|c|c|c|c|c|c|c|}
\hline units & Component & UDSLTF-1 & UDSLTF-2 & UDSNH-1A & UDSNH-1B & UDSNH-2A & UDSNH-2B \\
\hline $\mathrm{dps} / \mathrm{mL}$ & Eu-154 & 85.6 & 80.7 & $\mathrm{BDL}$ & 11.1 & 33.4 & 18.4 \\
\hline $\mathrm{dps} / \mathrm{mL}$ & Cs-137 & 599 & 596 & 407 & 725 & 613 & 780 \\
\hline $\mathrm{dps} / \mathrm{mL}$ & Co-60 & 9.92 & 11.7 & $\mathrm{BDL}$ & 2.05 & 9.91 & 11.9 \\
\hline $\mathrm{mg} / \mathrm{kg}$ & Aluminum & $5.18 \mathrm{E}+05$ & $2.84 \mathrm{E}+05$ & $\mathrm{~N} / \mathrm{A}$ & N/A & N/A & $\mathrm{N} / \mathrm{A}$ \\
\hline $\mathrm{mg} / \mathrm{kg}$ & Zirconium & 9557.02 & 15947.5 & N/A & $\mathrm{N} / \mathrm{A}$ & $\mathrm{N} / \mathrm{A}$ & $\mathrm{N} / \mathrm{A}$ \\
\hline $\mathrm{mg} / \mathrm{kg}$ & Calcium & $6.15 \mathrm{E}+03$ & $6.40 \mathrm{E}+03$ & N/A & $\mathrm{N} / \mathrm{A}$ & $\mathrm{N} / \mathrm{A}$ & $\mathrm{N} / \mathrm{A}$ \\
\hline $\mathrm{Wt} \%$ & Sodium & 4.35 & 3.16 & $N / A$ & $\mathrm{~N} / \mathrm{A}$ & $\mathrm{N} / \mathrm{A}$ & $\mathrm{N} / \mathrm{A}$ \\
\hline $\mathrm{mg} / \mathrm{kg}$ & Molybdenum & $<147.40$ & $<151.78$ & $\mathrm{~N} / \mathrm{A}$ & $\mathrm{N} / \mathrm{A}$ & N/A & $\mathrm{N} / \mathrm{A}$ \\
\hline $\mathrm{Wt} \%$ & Potassium & 3.75 & 3.85 & N/A & $\mathrm{N} / \mathrm{A}$ & $\mathrm{N} / \mathrm{A}$ & $\mathrm{N} / \mathrm{A}$ \\
\hline $\mathrm{mg} / \mathrm{kg}$ & Iron & 4560.43 & 6820.84 & $N / A$ & $\mathrm{~N} / \mathrm{A}$ & $\mathrm{N} / \mathrm{A}$ & $\mathrm{N} / \mathrm{A}$ \\
\hline $\mathrm{mg} / \mathrm{kg}$ & Chromium & 533.08 & 585.3 & N/A & $\mathrm{N} / \mathrm{A}$ & $\mathrm{N} / \mathrm{A}$ & $\mathrm{N} / \mathrm{A}$ \\
\hline $\mathrm{mg} / \mathrm{kg}$ & Magnesium & 1902.12 & 1827.62 & N/A & N/A & $\mathrm{N} / \mathrm{A}$ & $\mathrm{N} / \mathrm{A}$ \\
\hline $\mathrm{mg} / \mathrm{kg}$ & Rhodium & $<96.92$ & $<99.80$ & N/A & $\mathrm{N} / \mathrm{A}$ & $\mathrm{N} / \mathrm{A}$ & $\mathrm{N} / \mathrm{A}$ \\
\hline $\mathrm{mg} / \mathrm{kg}$ & Niobium & 95.91 & 948.12 & N/A & $\mathrm{N} / \mathrm{A}$ & $\mathrm{N} / \mathrm{A}$ & $\mathrm{N} / \mathrm{A}$ \\
\hline $\mathrm{mg} / \mathrm{kg}$ & Manganese & 3751.73 & 4328.91 & $\mathrm{~N} / \mathrm{A}$ & N/A & $\mathrm{N} / \mathrm{A}$ & $\mathrm{N} / \mathrm{A}$ \\
\hline $\mathrm{mg} / \mathrm{kg}$ & Nickel & 433.13 & 1494.95 & N/A & $\mathrm{N} / \mathrm{A}$ & $\mathrm{N} / \mathrm{A}$ & $\mathrm{N} / \mathrm{A}$ \\
\hline $\mathrm{mg} / \mathrm{kg}$ & Palladium & $<1361.97$ & $<1402.43$ & N/A & $\mathrm{N} / \mathrm{A}$ & $\mathrm{N} / \mathrm{A}$ & $\mathrm{N} / \mathrm{A}$ \\
\hline $\mathrm{mg} / \mathrm{kg}$ & Tin & $<313.99$ & 2413.96 & $\mathrm{~N} / \mathrm{A}$ & $\mathrm{N} / \mathrm{A}$ & $\mathrm{N} / \mathrm{A}$ & $\mathrm{N} / \mathrm{A}$ \\
\hline $\mathrm{mg} / \mathrm{kg}$ & Copper & 196.88 & 569.7 & $\mathrm{~N} / \mathrm{A}$ & N/A & $\mathrm{N} / \mathrm{A}$ & $\mathrm{N} / \mathrm{A}$ \\
\hline $\mathrm{mg} / \mathrm{kg}$ & Cadmium & 215.1 & 266.1 & N/A & N/A & $\mathrm{N} / \mathrm{A}$ & $\mathrm{N} / \mathrm{A}$ \\
\hline $\mathrm{mg} / \mathrm{kg}$ & Silver & 112.07 & 118.52 & $\mathrm{~N} / \mathrm{A}$ & $\mathrm{N} / \mathrm{A}$ & $\mathrm{N} / \mathrm{A}$ & $\mathrm{N} / \mathrm{A}$ \\
\hline $\mathrm{mg} / \mathrm{kg}$ & Cerium & $<154.47$ & $<159.06$ & $\mathrm{~N} / \mathrm{A}$ & N/A & $\mathrm{N} / \mathrm{A}$ & $\mathrm{N} / \mathrm{A}$ \\
\hline $\mathrm{mg} / \mathrm{kg}$ & Lead & 500.77 & 633.12 & N/A & N/A & $\mathrm{N} / \mathrm{A}$ & $\mathrm{N} / \mathrm{A}$ \\
\hline $\mathrm{mg} / \mathrm{kg}$ & Barium & 112.07 & 125.8 & N/A & N/A & $\mathrm{N} / \mathrm{A}$ & $\mathrm{N} / \mathrm{A}$ \\
\hline $\mathrm{mg} / \mathrm{kg}$ & Uranium & $<1020.72$ & $<1051.04$ & N/A & N/A & $\mathrm{N} / \mathrm{A}$ & $\mathrm{N} / \mathrm{A}$ \\
\hline $\mathrm{mg} / \mathrm{kg}$ & Gadolinium & 240.29 & 270.3 & $\mathrm{~N} / \mathrm{A}$ & N/A & $\mathrm{N} / \mathrm{A}$ & $\mathrm{N} / \mathrm{A}$ \\
\hline $\mathrm{mg} / \mathrm{kg}$ & Strontium & 199.9 & 275.5 & N/A & N/A & $\mathrm{N} / \mathrm{A}$ & $\mathrm{N} / \mathrm{A}$ \\
\hline $\mathrm{mg} / \mathrm{kg}$ & Neodimium & $<176.68$ & $<181.93$ & $N / A$ & $N / A$ & N/A & N/A \\
\hline $\mathrm{dps} / \mathrm{mL}$ & Technetium & N/A & N/A & 5.822 & 3.344 & $\mathrm{~N} / \mathrm{A}$ & $\mathrm{N} / \mathrm{A}$ \\
\hline $\mathrm{dps} / \mathrm{mL}$ & lodine & $\mathrm{N} / \mathrm{A}$ & N/A & ND & 0.205 & $\mathrm{~N} / \mathrm{A}$ & $\mathrm{N} / \mathrm{A}$ \\
\hline $\mathrm{mg} / \mathrm{kg}$ & Ruthenium & $\mathrm{N} / \mathrm{A}$ & $\mathrm{N} / \mathrm{A}$ & $<268.49$ & $<271.13$ & $\mathrm{~N} / \mathrm{A}$ & $\mathrm{N} / \mathrm{A}$ \\
\hline $\mathrm{mg} / \mathrm{kg}$ & Selenium & $\mathrm{N} / \mathrm{A}$ & $\mathrm{N} / \mathrm{A}$ & $<1013.51$ & $<1023.45$ & $\mathrm{~N} / \mathrm{A}$ & $\mathrm{N} / \mathrm{A}$ \\
\hline $\mathrm{mg} / \mathrm{kg}$ & Boron & $\mathrm{N} / \mathrm{A}$ & N/A & $<472.43$ & $<477.06$ & N/A & $\mathrm{N} / \mathrm{A}$ \\
\hline WT\% & Mercury & $\mathrm{N} / \mathrm{A}$ & N/A & N/A & $\mathrm{N} / \mathrm{A}$ & 0.139 & 0.062 \\
\hline WT\% & Sulfate & $\mathrm{N} / \mathrm{A}$ & $N / A$ & 0.1957 & 0.1245 & N/A & N/A \\
\hline WT\% & Nitrate & $\mathrm{N} / \mathrm{A}$ & $\mathrm{N} / \mathrm{A}$ & 1.71 & 1.52 & $\mathrm{~N} / \mathrm{A}$ & $\mathrm{N} / \mathrm{A}$ \\
\hline WT\% & Chloride & $\mathrm{N} / \mathrm{A}$ & N/A & 0.013 & 0.03 & N/A & N/A \\
\hline WT\% & Flouride & N/A & $N / A$ & N/A & N/A & $<1.57$ & 1.8 \\
\hline
\end{tabular}

Less than indicates result is at or below analytical detection limit. 
Dissolved solution and off-gas data

\begin{tabular}{|c|c|c|c|c|c|c|c|}
\hline units & Component & Diss-1 & Diss-2 & CS-1 & CS-2 & AS-1 & AS-2 \\
\hline $\mathrm{dps} / \mathrm{mL}$ & Eu-154 & $2.23 E+03$ & $2.49 \mathrm{E}+03$ & $\mathrm{BDL}$ & $\mathrm{BDL}$ & $\mathrm{BDL}$ & BDL \\
\hline $\mathrm{dps} / \mathrm{mL}$ & Cs-137 & $1.04 \mathrm{E}+06$ & $1.01 E+06$ & 5.9 & 3.31 & 6.12 & 5.55 \\
\hline $\mathrm{dps} / \mathrm{mL}$ & Co-60 & 241 & 301 & $\mathrm{BDL}$ & $\mathrm{BDL}$ & $\mathrm{BDL}$ & $\mathrm{BDL}$ \\
\hline $\mathrm{mg} / \mathrm{kg}$ & Aluminum & $3.55 E+05$ & $3.25 E+05$ & $\mathrm{~N} / \mathrm{A}$ & $\mathrm{N} / \mathrm{A}$ & $\mathrm{N} / \mathrm{A}$ & N/A \\
\hline $\mathrm{mg} / \mathrm{kg}$ & Zirconium & 1869.32 & 1837.28 & $\mathrm{~N} / \mathrm{A}$ & $\mathrm{N} / \mathrm{A}$ & $\mathrm{N} / \mathrm{A}$ & N/A \\
\hline $\mathrm{mg} / \mathrm{kg}$ & Calcium & $3.67 E+04$ & $3.65 E+04$ & $\mathrm{~N} / \mathrm{A}$ & $\mathrm{N} / \mathrm{A}$ & $\mathrm{N} / \mathrm{A}$ & N/A \\
\hline $\mathrm{Wt} \%$ & Sodium & 10.68 & 10.22 & $\mathrm{~N} / \mathrm{A}$ & $\mathrm{N} / \mathrm{A}$ & $\mathrm{N} / \mathrm{A}$ & N/A \\
\hline $\mathrm{mg} / \mathrm{kg}$ & Molybdenum & 73.24 & 73.48 & $\mathrm{~N} / \mathrm{A}$ & $\mathrm{N} / \mathrm{A}$ & $\mathrm{N} / \mathrm{A}$ & N/A \\
\hline $\mathrm{Wt} \%$ & Potassium & 1.41 & 1.46 & $\mathrm{~N} / \mathrm{A}$ & $\mathrm{N} / \mathrm{A}$ & $\mathrm{N} / \mathrm{A}$ & N/A \\
\hline $\mathrm{mg} / \mathrm{kg}$ & Iron & 2612.32 & 2600.76 & $\mathrm{~N} / \mathrm{A}$ & $\mathrm{N} / \mathrm{A}$ & $\mathrm{N} / \mathrm{A}$ & N/A \\
\hline $\mathrm{mg} / \mathrm{kg}$ & Chromium & 527.04 & 517.75 & N/A & $\mathrm{N} / \mathrm{A}$ & $\mathrm{N} / \mathrm{A}$ & N/A \\
\hline $\mathrm{mg} / \mathrm{kg}$ & Magnesium & 939.44 & 960.42 & $\mathrm{~N} / \mathrm{A}$ & $\mathrm{N} / \mathrm{A}$ & $\mathrm{N} / \mathrm{A}$ & N/A \\
\hline $\mathrm{mg} / \mathrm{kg}$ & Rhodium & $<2.02$ & $<2.02$ & $\mathrm{~N} / \mathrm{A}$ & $\mathrm{N} / \mathrm{A}$ & $\mathrm{N} / \mathrm{A}$ & N/A \\
\hline $\mathrm{mg} / \mathrm{kg}$ & Niobium & 2.46 & 1.95 & $\mathrm{~N} / \mathrm{A}$ & $\mathrm{N} / \mathrm{A}$ & $\mathrm{N} / \mathrm{A}$ & N/A \\
\hline $\mathrm{mg} / \mathrm{kg}$ & Manganese & 2232.58 & 2276.51 & $\mathrm{~N} / \mathrm{A}$ & $\mathrm{N} / \mathrm{A}$ & $\mathrm{N} / \mathrm{A}$ & N/A \\
\hline $\mathrm{mg} / \mathrm{kg}$ & Nickel & 220.06 & 214.93 & $\mathrm{~N} / \mathrm{A}$ & $N / A$ & $N / A$ & $\mathrm{~N} / \mathrm{A}$ \\
\hline $\mathrm{mg} / \mathrm{kg}$ & Paladium & $<28.33$ & $<28.31$ & $\mathrm{~N} / \mathrm{A}$ & $\mathrm{N} / \mathrm{A}$ & $\mathrm{N} / \mathrm{A}$ & N/A \\
\hline $\mathrm{mg} / \mathrm{kg}$ & Tin & 7.85 & 17.46 & N/A & $\mathrm{N} / \mathrm{A}$ & $\mathrm{N} / \mathrm{A}$ & N/A \\
\hline $\mathrm{mg} / \mathrm{kg}$ & Copper & 105.39 & 107.03 & $\mathrm{~N} / \mathrm{A}$ & $\mathrm{N} / \mathrm{A}$ & $\mathrm{N} / \mathrm{A}$ & N/A \\
\hline $\mathrm{mg} / \mathrm{kg}$ & Cadmium & 348.8 & 352.2 & $\mathrm{~N} / \mathrm{A}$ & N/A & $\mathrm{N} / \mathrm{A}$ & $\mathrm{N} / \mathrm{A}$ \\
\hline $\mathrm{mg} / \mathrm{kg}$ & Silver & $<0.44$ & $<0.44$ & $\mathrm{~N} / \mathrm{A}$ & $\mathrm{N} / \mathrm{A}$ & $\mathrm{N} / \mathrm{A}$ & $\mathrm{N} / \mathrm{A}$ \\
\hline $\mathrm{mg} / \mathrm{kg}$ & Cerium & 13.5 & 14.19 & $\mathrm{~N} / \mathrm{A}$ & $\mathrm{N} / \mathrm{A}$ & $\mathrm{N} / \mathrm{A}$ & $\mathrm{N} / \mathrm{A}$ \\
\hline $\mathrm{mg} / \mathrm{kg}$ & Lead & 914.04 & 908.22 & $\mathrm{~N} / \mathrm{A}$ & $\mathrm{N} / \mathrm{A}$ & $\mathrm{N} / \mathrm{A}$ & $\mathrm{N} / \mathrm{A}$ \\
\hline $\mathrm{mg} / \mathrm{kg}$ & Barium & 12.47 & 13.5 & $\mathrm{~N} / \mathrm{A}$ & $\mathrm{N} / \mathrm{A}$ & $\mathrm{N} / \mathrm{A}$ & $\mathrm{N} / \mathrm{A}$ \\
\hline $\mathrm{mg} / \mathrm{kg}$ & Uranium & 260.58 & 240.12 & $\mathrm{~N} / \mathrm{A}$ & $\mathrm{N} / \mathrm{A}$ & $\mathrm{N} / \mathrm{A}$ & N/A \\
\hline $\mathrm{mg} / \mathrm{kg}$ & Gadolinium & 171.3 & 166.78 & $\mathrm{~N} / \mathrm{A}$ & $\mathrm{N} / \mathrm{A}$ & $\mathrm{N} / \mathrm{A}$ & N/A \\
\hline $\mathrm{mg} / \mathrm{kg}$ & Strontium & 144.91 & 143.99 & $\mathrm{~N} / \mathrm{A}$ & $\mathrm{N} / \mathrm{A}$ & $\mathrm{N} / \mathrm{A}$ & N/A \\
\hline $\mathrm{mg} / \mathrm{kg}$ & Neodimium & 29.08 & 29.53 & $N / A$ & N/A & $\mathrm{N} / \mathrm{A}$ & N/A \\
\hline $\mathrm{dps} / \mathrm{mL}$ & Technetium & 812.63 & 11602 & 0.141 & 0.18 & $\mathrm{~N} / \mathrm{A}$ & $\mathrm{N} / \mathrm{A}$ \\
\hline $\mathrm{dps} / \mathrm{mL}$ & lodine & $<0.25$ & ND & ND & $<8.07 \mathrm{E}-02$ & $\mathrm{~N} / \mathrm{A}$ & $\mathrm{N} / \mathrm{A}$ \\
\hline $\mathrm{mg} / \mathrm{kg}$ & Ruthenium & 55.67 & 52.24 & $<0.55$ & $<0.55$ & $\mathrm{~N} / \mathrm{A}$ & N/A \\
\hline $\mathrm{mg} / \mathrm{kg}$ & Selenium & $<6.09$ & 10.79 & N/A & N/A & $\mathrm{N} / \mathrm{A}$ & N/A \\
\hline $\mathrm{mg} / \mathrm{kg}$ & Boron & $6.38 \mathrm{E}+03$ & $5.72 \mathrm{E}+03$ & $\mathrm{~N} / \mathrm{A}$ & N/A & $\mathrm{N} / \mathrm{A}$ & N/A \\
\hline WT\% & Mercury & 0.0019 & 0.0015 & $<0.0031$ & $<0.0031$ & $<0.0031$ & $<0.0031$ \\
\hline WT\% & Sulfate & 0.95 & 0.99 & N/A & N/A & N/A & N/A \\
\hline WT\% & Nitrate & ND & ND & $<0.050$ & $<0.050$ & $N / A$ & N/A \\
\hline WT\% & Chloride & $<0.1200$ & 0.101 & $<0.012$ & $<0.012$ & $<0.012$ & $<0.012$ \\
\hline WT\% & Flouride & 1.6 & 0.39 & $\mathrm{~N} / \mathrm{A}$ & $N / A$ & N/A & N/A \\
\hline
\end{tabular}

Less than indicates result is at or below analytical detection limit. 
WM-185 aluminum nitrate blend elemental material balance sample cross reference guide

\begin{tabular}{|c|c|}
\hline CalcLTF-1 = & Initial calcine using lithium tetraborate fusion dissolution \#1 \\
\hline CalcLTF-2 = & Initial calcine using lithium tetraborate fusion dissolution \#2 \\
\hline CalcNH-1A = & Initial calcine using sodium hydroxide fusion dissolution \#1 \\
\hline CalcNH-1B $=$ & Initial calcine using sodium hydroxide fusion dissolution \#1 (Tc and I spike) \\
\hline CalcNH-2A = & Initial calcine using sodium hydroxide fusion dissolution \#2 \\
\hline CalcNH-2B = & Initial calcine using sodium hydroxide fusion dissolution \#2 (Tc and I spike) \\
\hline UDSLTF-1 = & UDS lithium tetraborate fusion dissolution \#1 \\
\hline UDSLTF-2 = & UDS lithium tetraborate fusion dissolution \#2 \\
\hline UDSNH-1A = & UDS sodium hydroxide fusion dissolution \#1 \\
\hline UDSNH-1B = & UDS sodium hydroxide fusion dissolution \#1 (Tc and I spike) \\
\hline UDSNH-2A $=$ & UDS sodium hydroxide fusion dissolution \#2 \\
\hline UDSNH-2B = & UDS sodium hydroxide fusion dissolution \#2 (Tc and I spike) \\
\hline Diss-1 & Dissolved solution from dissolution \#1 \\
\hline Diss-2 & Dissolved solution from dissolution \#2 \\
\hline As-1 & Acid scrub solution dissolution \#1 \\
\hline Cs-1 & Caustic scrub solution dissolution \#1 \\
\hline As-2 & Acid scrub solution dissolution \#2 \\
\hline Cs-2 & Caustic scrub solution dissolution \#2 \\
\hline
\end{tabular}




\section{Elemental material balance unit conversions}

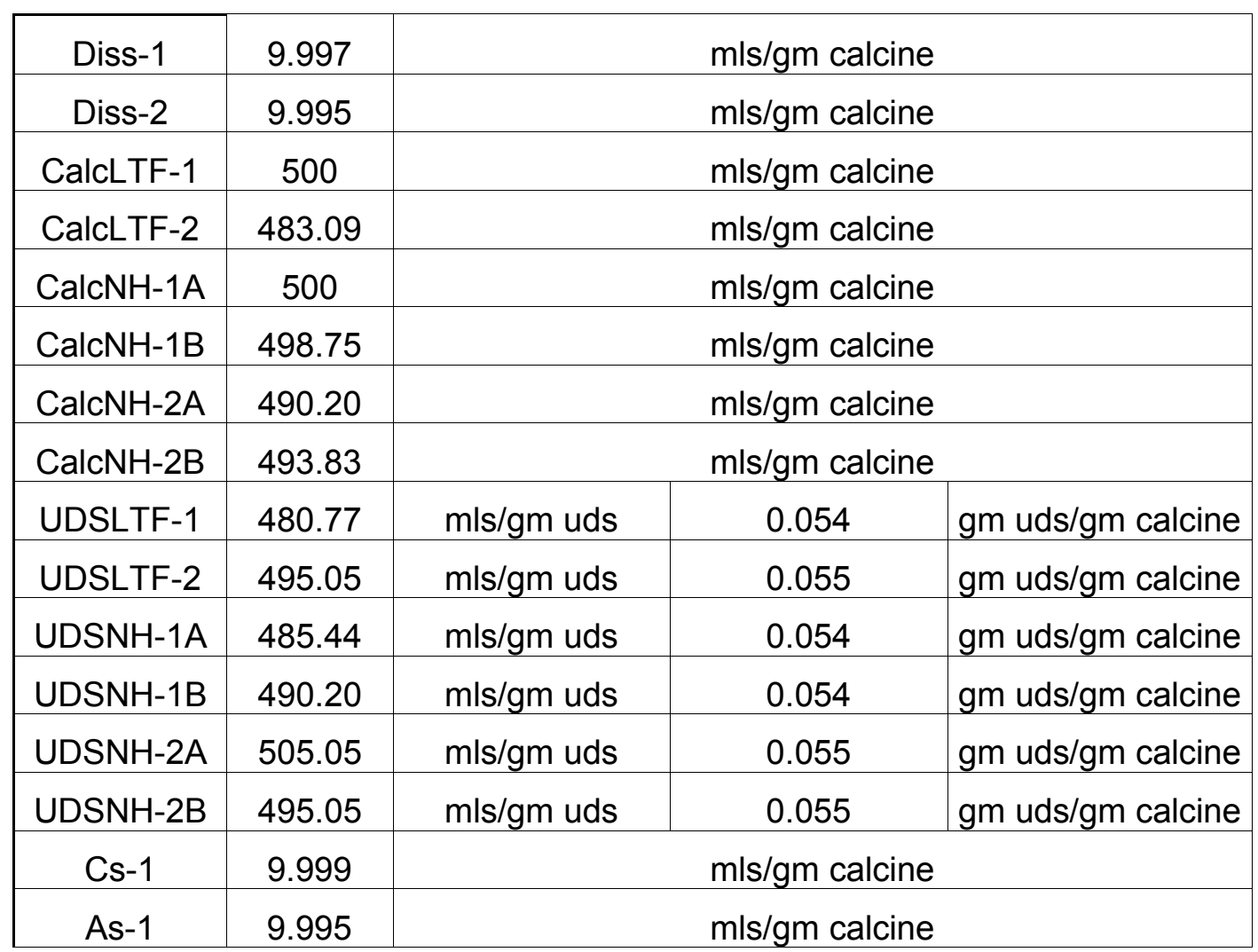

